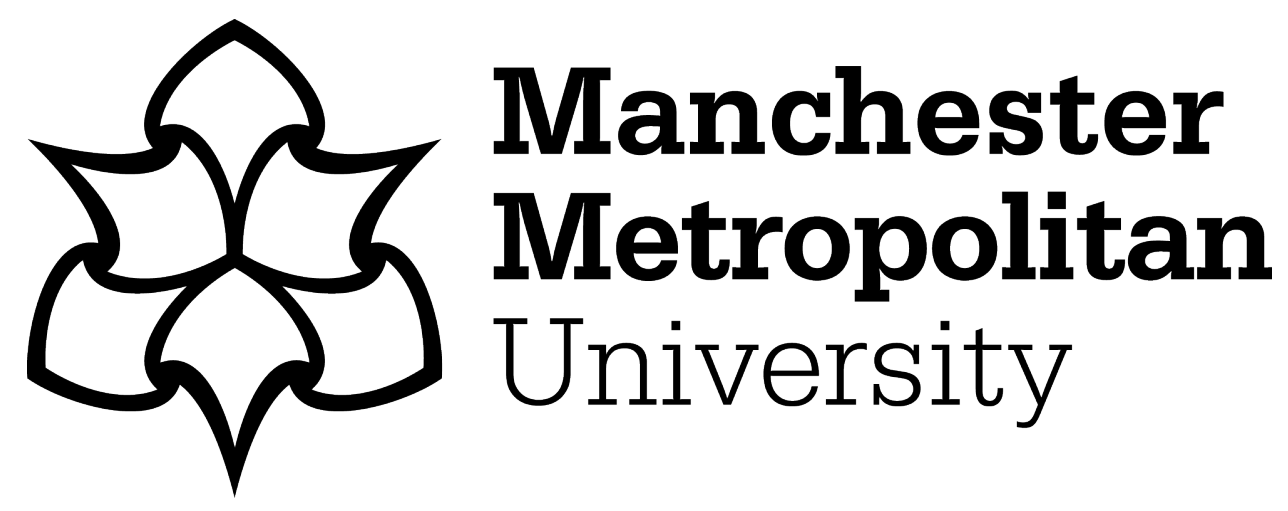

Wood, Geoffrey, Finnegan, Jared J, Allen, Maria L, Allen, Matthew MC, Cumming, Douglas, Johan, Sofia, Nicklich, Manuel, Endo, Takahiro, Lim, Sijeong and Tanaka, Seiki (2020) The comparative institutional analysis of energy transitions. Socio-Economic Review, 18 (1). pp. 257-294. ISSN 1475-1461

Downloaded from: https://e-space.mmu.ac.uk/624637/

Version: Accepted Version

Publisher: Oxford University Press (OUP)

DOI: https://doi.org/10.1093/ser/mwz026

Please cite the published version 


\title{
The comparative institutional analysis of energy transitions
}

\author{
Geoffrey Wood, Jared J. Finnegan, Maria L. Allen \\ Matthew M. C. Allen, Douglas Cumming, Sofia Johan \\ Manuel Nicklich, Takahiro Endo, Sijeong Lim and Seiki Tanaka
}

\begin{abstract}
The discussion on 'The comparative institutional analysis of energy transitions' gives us a state-of-the-art overview of the main theoretical and conceptual developments within the field of political economy. It invites us to broaden our knowledge on the changing realities of different geographical regions in energy transition. In this discussion forum, Finnegan discusses emerging themes in the comparative political economy literature of climate change. He identifies gaps and offers an outline for further research. Allen, Allen, Cumming and Johan take a closer look at the links between different types of capitalism and the natural environment. The authors stress the importance of adopting an institutional perspective to explain differences in environmental outcomes. Wood compares the transitions of energy usage and mixes between liberal and coordinated market economies from a historical perspective. He looks for parallels between the energy transition from coal to oil and gas to the current renewables. Nicklich and Endo answer the question 'Do globalization and globally perceived occurrences of environmental problems lead to a convergence of energy supply?'. They compare the fields of German and Japanese wind power with a particular focus on Greenpeace after the Fukushima disaster in 2011. Finally, Lim and Tanaka focus on the question 'When do energy transition policies enjoy broad-based acceptance?'. They conclude that the public acceptance of energy transition varies between Western and non-Western societies.
\end{abstract}

Key words: varieties of capitalism, comparative politics, energy, industrial change, political economy

JEL classification: 013 economic development: agriculture, natural resources, energy, environment, other primary products, P18 capitalist systems: energy, environment, 042 alternative energy sources 


\section{Shifting focus: why comparative political economy should engage (again) with the politics of growth}

\section{Geoffrey Wood*}

Western University, Ontario

*Correspondence: gwood23@uwo.ca

\section{Introduction}

The many manifestations of comparative institutional analysis, which extend from property rights perspectives to the radical political economy of regulation theory, has had an undeniable influence on a wide range of fields, stretching from corporate finance through to human resource management. More recently, there have been attempts to systematically compare and contrast, and/or synthesize elements of aspects of these very different traditions, leading (a) to an increased emphasis on the temporary nature of any institutional fix and (b) authors from a wide range of starting points to conclude that there are strong universal pressures to liberalization. However, the scope of issues encompassed in such analysis has focused on the traditional mix of regulation, associational ties and firmlevel practices; this article supplements this literature by focusing on a key material dimension bound up with capitalist diversity: energy usages and mixes. We explain the reasons for these connections and place them in long-term historical perspective. We go on to highlight likely trajectories and discuss the implications for comparative institutional analysis.

\section{Origins of different forms of capitalism}

Dramatic economic upsurges have been noted in a wide range of societies, but each incorporates a unique mix of elements (Goldstone, 2002; Wood, 2015, 2016). It has been widely noted that the Italian renaissance was kick started by a large infusion of free capital, which, in turn, flowed from the sack of Constantinople (Runciman, 1970; Angold, 2014). Similarly, Spain's great power status flowed from large infusions of expropriated gold from the New World, even though the latter led to unexpected problems of inflation (Vilches, 2010). The expropriation of domestic peasants constitutes a key phase of capitalist development (Perelman, 2000; Streeck, 2011); however, the effects of the latter may be dwarfed by outward primitive expropriation disposing the lands and capturing the labor of outsiders located beyond the initial metropole.

A common feature of all mature liberal markets was primitive acts of expropriation at a formative stage, but was distinctive that this was combined with a new found 'ability to extract motive power from coal, to a degree rarely appreciated by historians' (Golstone, 2002, p. 323). In the case of England, the primitive expropriation centered on the looting of India and the slave trade; however, economic historians are divided as to the relative impact of 
each (Engerman, 1972; Inikori, 2002; Mantoux, 2013). The remaining mature liberal markets-Australia and the USA, Canada and New Zealand-were formed out of the expropriation of the indigenous population, and hence free land and mineral resources (McNeil, 2004; Wunder and Hu-DeHart, 1992). This took a lot more brutal form in the former two countries, and it could be argued that a modicum of restraint on account of realism or convenience might at least partially help to explain why the latter two represent softer manifestations of market liberalism. In any event, this would be a possibility worth considering.

What this 'original sin' means is that a guiding principle of law in liberal markets was not so much the universal protection of private property rights (cf. La Porta et al., 1999), but rather the legitimation and embedding of what was often dubiously acquired (Blomley, 2003). Again, this would also mean that the allocation and re-allocation of capital received a higher priority than ensuring productive mechanisms for the increase in capital. This is not to suggest that liberal markets constituted (or constitute) monocultures, and, indeed, there are areas of liberal markets where value is generated through longerterm production paradigms. However, at the same time, there exists a stronger tendency to maximize wealth through non-productive activities, and, indeed, in the age of financialization, this has attained ecosystemic dominance (Lazonick, 2010). The two largest liberal markets continue to be sustained through infusions of cheap (but no longer free) capital from abroad, reflecting inter alia the historical dominance of the dollar, open financial markets and part of a Faustian bargain by net exporting nations (Epstein, 2005; Chuhan et al., 1996).

In contrast to primitive expropriation of outsiders, coordinated markets largely owe their existence to internally generated productive systems (Boyer, 2005; Wood, 2015, 2016). Developing and sustaining such systems is always challenging, and, indeed, there have been periods when major coordinated markets have experimented with the alternative (Tierney, 2010). This is not to suggest that each archetype did not share features, or indeed, incorporate sub-ecosystems more commonly associated with the other (Allen, 2013).

On the one hand, the formation of distinct types of capitalism took place long in the past, and would seem scarcely relevant to the present condition. On the other hand, different historical experiences mean that contrasting systems have different mechanisms in their standard policy arsenal to cope with crisis, and the default (but not inevitable) pattern of indigenous capital follows very long traditions. This does not mean that all capital in liberal markets is short termist, simply that there are strong short-term tendencies and these are brought to the fore by long crises.

\section{Varieties of energy transition}

Although parallels have been widely drawn between the early to mid-20th century and the present condition, they have mostly focused on the symptoms each has presented rather than on the underlying commonalities in material causes (Piketty, 2015). However, it is worth noting that the earlier crisis was also a time of a long energy transition whereby the world underwent a long transition from coal, to oil and gas. This long energy transition fundamentally challenged existing allocations of capital and labor as well as the relative positions of regions and nations (Fouquet, 2010; Wood, 2015, 2016). Those with sunk assets-patient investors and workers-in specific industries 
and processes lost out, while more mobile investors were able to capitalize on the new opportunities this opened up, and, indeed, from the chances presented by the crisisfuelled volatility (Wood, 2015, 2016). Mobile investors were, of course, the archetypical rentiers (Piketty, 2015). For the broad historical reasons noted above, they were particularly concentrated in liberal markets. Again, as liberal markets were simply better at primitive expropriation, they had, either under direct control or through extended imperialism, a greater amount of oil and gas under their control or behest than almost all of the other advanced societies (Mazaheri, 2014).

In contrast, lacking the same degree of access to raw materials, and operating in an investment ecosystem that encouraged a greater commitment of capital, coordinated markets faced greater existential threats as a result of this transition. Many developed economies suffered grave financial crisis, and, of course, the associated wars engulfed almost all. However, liberal markets were able to set themselves back on a pattern of growth sooner, even if this did entail messy compromises that diluted some components of the model. Most notably, it was necessary to reach some compromises with labor and extend a basic degree of social protection in order to buy social stability (Daguerre, 2014).

Since the 1970s, the developed world has again entered a long period of mediocre or volatile growth and recession. Once more, this has coincided with fundamental changes in the energy ecosystem. For structural supply reasons, oil is no longer as cheap as it was, and, indeed, for the last decade, while usage has increased, oil and gas have declined as a proportion of the global energy mix: we are already in a long energy transition (Tatebe, 2013; Ulrichsen, 2014). Again, this has changed the cost-and predictability of the costs of inputs-and accordingly affected regions' and nations' sources of competitiveness. While the effects have been felt throughout the developed world, the scale and scope of the crisis have been uneven (Tatebe, 2013; Wood, 2015, 2016).

Initially, it was assumed that the coordinated markets were the ones that had lost out from this period of turbulence, and, indeed, proponents of neo-liberalism were quick to seize the policy commanding heights (Overbeek, 2002). However, more recently, coordinated markets have become seen as islands of stability, while the two largest liberal markets have been engulfed by unprecedented political crisis, reflecting a fundamental breakdown of the social contract (Colgan and Keohane, 2017). Again, it might seem that rentiers, rather than patient capital, were the ones who had the most to benefit from the change. Again, macro-economic turbulence did open up new opportunities for those who could rapidly move their capital around. However, in general, renewable energy is more conducive to patient investors: high set-up costs are followed by lower maintenance costs and longer-term revenue flows (Wood, 2015, 2016; Masini and Menichetti, 2012). In contrast, the oil and gas industry-and particularly the unconventional sources that have assumed an increasing proportion of the industry's attention and capitalhave become associated with every shorter timelines and every more exotic financialization (cf. Labban, 2010).

It would be crudely determinist to assume that the links between these various elements are close and direct; however, long-term systemic crisis and change is a dynamic and contested process, and no institutional regime is ever completely coherent or closely coupled (Lane and Wood, 2009). At the same time, renewables are best served by quite different types of investors to the contemporary oil and gas industry; the former are more long termist 
than the latter. Again, common external pressures notwithstanding, coordinated markets are much better in promoting and sustaining longer-term investment, and this is bound up with long historical legacies.

In taking a long-term historical view that links the uneven effects and consequences of economic crisis, it is necessary to account for a further element: technology. Technological advances make shifts in energy mixes possible, but, by the same measure, it is changes in the cost and availability of different energy sources that drive new investment in R\&D, and, indeed, technological outcomes (Goldstone, 2002). Rather than assuming causality, it should be recognized that technology is an important component of the mix, and that it may accelerate or constrain change (Ellabban et al., 2014). Again, it cannot be assumed that technology always has benign effects; moreover, technologies may incorporate hidden costs that only slowly become visible (Diamond, 1998). At the same time, progress in renewables incorporates a strong incremental element, that, longer term, may be better sustained in more coordinated economies.

Finally, we would be wrong to presume that when it comes to the broad question of long energy transitions, liberal market governments are more hands off. In all developed societies, state policies have exerted strong effects on energy mixes, including relative investment in renewables (Lehmann et al., 2017). However, in the case of liberal markets, increasingly right-wing governments have placed barriers against the adoption of renewables, and devised complex mixes of subsidies to favor hydrocarbons (Mayer and Smith, 2017; Hinman, 2018; Peters, 2018; Ramsay, 2018). While liberal markets seem to have a very much stronger commitment to the latter, it certainly is not market driven. This would further highlight the point that not only does any long period of market dominance may lead to renewed statism, but statism may assume many forms, not all benign (Wood and Wright, 2015).

\section{Conclusions}

The 2018 Society for the Advancement of Socio-Economics (SASE) mini-conference on energy transitions and comparative capitalism and the coterminous Kyoto Institute of Economic Research Symposium brought together a cross section of papers that presented new research and evidence that pointed to varieties in the scope and scale in which different types of capitalism have embraced the long energy transition. The purpose of this discussion forum is to explore what the underlying reasons behind this variety might be. As noted above, long periods of global crisis affect all capitalisms, and there are many homogenizing pressures. However, by the same measure, the effects have been very uneven: more coordinated markets seem to be more rapidly making the transition over to renewables. Again, the relative ability and willingness to make the transition is partially bound up not only with government policy, but also with investment ecosystems, which, in turn, will develop, in part, from long historical legacies. Finally, institutional arrangements are never perfectly coupled (Lane and Wood, 2009). A focus on broad trends must perforce recognize this: any trends will always be uneven, and incorporate internal contradictions. Hence, while coordinated markets have progressed furthest to renewables, this is not to suggest that the process is even, fully coherent and does not incorporate important counter tendencies. Nonetheless, there are important variations in energy policy and trends in energy mixes that coincide with the generally accepted national institutional archetypes. 
Taking account of this, the uneven nature in which the associated economic crisis has played out, and, indeed, variations in national political crises represent important elements that need to be more fully incorporated into the literature on comparative capitalism.

\section{References}

Allen, M. M. C. (2013) 'Comparative Capitalisms and the Institutional Embeddedness of Innovative Capabilities', Socio-Economic Review, 11, 771-794.

Angold, M. (2014) The Fall of Constantinople to the Ottomans: Context and Consequences. Abingdon, Routledge.

Blomley, N. (2003) 'Law, Property, and the Geography of Violence: The Frontier, the Survey, and the Grid', Annals of the Association of American Geographers, 93, 121-141.

Boyer, R. (2005) 'How and Why Capitalisms Differ', Economy and Society, 34, 509-557.

Chuhan, P., Perez-Quiros, G. and Popper, H. (1996) International Capital Flows: Do Short-Term Investment and Direct Investment Differ?. Washington, The World Bank.

Colgan, J. D. and Keohane, R. O. (2017) 'The Liberal Order Is Rigged: Fix It Now or Watch It Wither', Foreign Affairs, 96, 36.

Daguerre, A. (2014) 'New Corporate Elites and the Erosion of the Keynesian Social Compact', Work, Employment and Society, 28, 323-334.

Diamond, J. M. (1998) Guns, Germs and Steel: A Short History of Everybody for the Last 13,000 Years. New York, NY, Random House.

Ellabban, O., Abu-Rub, H. and Blaabjerg, F. (2014) 'Renewable Energy Resources: Current Status, Future Prospects and Their Enabling Technology', Renewable and Sustainable Energy Reviews, 39, 748-764.

Engerman, S. L. (1972) 'The Slave Trade and British Capital Formation in the Eighteenth Century: A Comment on the Williams Thesis', Business History Review, 46, 430-443.

Epstein, G. A. (ed.) (2005) Financialization and the World Economy. Cheltenham, Edward Elgar Publishing.

Fouquet, R. (2010) 'The Slow Search for Solutions: Lessons from Historical Energy Transitions by Sector and Service', Energy Policy, 38, 6586-6596.

Goldstone, J. A. (2002) 'Efflorescences and Economic Growth in World History: Rethinking the "Rise of the West" and the Industrial Revolution', Journal of World History, 13, 323-389.

Hinman, P. (2018) 'Gov't Giving Oil and Gas Away for Free', Green Left Weekly, 1173, 10.

Inikori, J. E. 2002. Africans and the Industrial Revolution in England: A Study in International Trade and Economic Development. Cambridge, Cambridge University Press.

Labban, M. (2010) 'Oil in Parallax: Scarcity, Markets, and the Financialization of Accumulation', Geoforum, 41, 541-552.

Lane, C. and Wood, G. (2009) 'Diversity in Capitalism and Capitalist Diversity', Economy and Society, 38, 531-551.

La Porta, R., Lopez-de-Silanes, F., Shleifer, A. and Vishny, R.. (1999) 'The Quality of Government', Journal of Law, Economics, and Organization, 15, 222-279.

Lazonick, W. (2010) 'Innovative business models and varieties of capitalism: Financialization of the US corporation', Business History Review, 84, 675-702.

Lehmann, P., Gawel, E. and Strunz, S. (2019) 'EU climate and energy policy beyond 2020: Are additional targets and instruments for renewables economically reasonable?', In Gawel, E., Strunz, S., Lehmann, P. and Purkus, A. (eds) The European Dimension of Germany's Energy Transition, Cham, Springer, pp. 11-26. 
Mantoux, P. (2013) The Industrial Revolution in the Eighteenth Century: An Outline of the Beginnings of the Modern Factory System in England. Abingdon, Routledge.

Masini, A. and Menichetti, E. (2012) 'The Impact of Behavioural Factors in the Renewable Energy Investment Decision Making Process: Conceptual Framework and Empirical Findings', Energy Policy, 40, 28-38.

Mayer, A. and Smith, E. K. (2017) 'Education, Political Affiliation and Energy Policy in the United States: A Case of Tea Party Exceptionalism?', Energy Research \& Social Science, 23, 74-81.

Mazaheri, N. (2014) 'Oil Wealth, Colonial Legacies, and the Challenges of Economic Liberalization', Political Research Quarterly, 67, 769-782.

McNeil, K. (2004) 'The Vulnerability of Indigenous Land Rights in Australia and Canada', Osgoode Hall Law Journal, 42, 271-301.

Overbeek, H. W. (ed.) (2002) Restructuring Hegemony in the Global Political Economy: The Rise of Transnational Neo-Liberalism in the 1980s. Abingdon, Routledge.

Perelman, M. (2000) The Invention of Capitalism: Classical Political Economy and the Secret History of Primitive Accumulation. Durham, Duke University Press.

Peters, B. G. (2018) American Public Policy: Promise and Performance. Thousand Oaks, CA, Sage.

Piketty, T. (2015) 'About Capital in the Twenty-First Century', American Economic Review, 105, $48-53$.

Ramsay, A. (2018) 'The Final Chapter for North Sea Oil', Soundings, 68, 26-39.

Runciman, S. (1970) The Last Byzantine Renaissance. Cambridge, Cambridge University Press.

Streeck, W. (2011) 'E Pluribus Unum? Varieties and Commonalities of Capitalism', Sociology of Economic Life, 3, 419-455.

Tatebe, M. (2013) 'The Global Financial Crisis As a World Great Depression: An Analysis Using Marxian Economics'. In Yogi, K., Yokokawa, N., Shinjiro, H. and Dymski, G. (eds) Crises of Global Economy and the Future of Capitalism. Abingdon, Routledge, pp. 97-112.

Tierney, R. T. (2010) Tropics of Savagery: The Culture of Japanese Empire in Comparative Frame, Vol. 5. Berkeley, University of California Press.

Ulrichsen, K. C. (2014) Insecure Gulf: The End of Certainty and the Transition to the Post-Oil Era. Oxford, Oxford University Press.

Vilches, E. (2010) New World Gold: Cultural Anxiety and Monetary Disorder in Early Modern Spain. Chicago, University of Chicago Press.

Wood, G. (2016) 'Persistent Crisis and Path Dependence: The Foundations and Boundaries of Systemic Change', Journal of Comparative Economic Studies, 11, 11-23.

Wood, G. (2015) 'Structural Crisis and Transitions: Present Issues and Potential Future Trajectories', Journal of Comparative Economic Studies, 10, 55-68.

Wood, G. and Wright, M. (2015) 'Corporations and New Statism: Trends and Research Priorities', Academy of Management Perspectives, 29, 271-286.

Wunder, D. and Hu-DeHart, E. (1992) The State of Native America: Genocide, Colonization, and Resistance. Boston, South End Press. 


\title{
Varieties of de-carbonization? Comparative political economy and climate change
}

\author{
Jared J. Finnegan \\ Department of Government and Grantham Research Institute on Climate Change and the \\ Environment, LSE \\ *Correspondence: j.finnegan@lse.ac.uk
}

\section{A challenge for comparative political economy}

Across the advanced capitalist democracies, climate change is one of the most difficult policy challenges governments face. Yet, it has been almost entirely ignored in mainstream comparative political economy (CPE). Indeed, while there is a broad and growing literature on climate change politics (for a review see Bernauer, 2013), what is conspicuously absent is cross-national climate policy research that takes seriously variation in the political and economic institutions that underpin distinct capitalist models; that is, a comparative political economy of climate change. Why do some high-income democracies consistently do more to address climate change compared to others? Are some political economies systematically better able to address long-term challenges like climate change? What is the relationship between capitalist diversity and climate policy? Between climate policy and the welfare state?

This short article describes key themes in the emerging CPE of climate change literature, identifies gaps and outlines avenues for future research. It is not a comprehensive literature review, but rather a short survey focusing exclusively on work that connects climate policy and the core institutions of advanced capitalist democracies. As I will show, CPE is particularly well-equipped to explain cross-national patterns of climate policy adoption and stringency. I hope to persuade comparative political economists to take climate change more seriously and hasten the emergence of a CPE of climate change research agenda and subfield.

\section{The puzzle and politics of climate change policy}

Despite the many challenges, governments across the high-income democracies have acted to address climate change since the late 1980s. Indeed, the puzzle is that the stringency of climate policy varies significantly across countries (Figure 1). Why? A theoretical starting point is to conceptualize climate change politics as distributive politics. Since addressing climate change requires long-term policy investments that entail short-term costs for greater longterm benefits, it generates distributive conflict along two axes: inter-temporal (whether and how much of today's resources are invested for future benefits) and cross-sectional (how short-term costs are distributed among actors today) (Jacobs, 2011; Finnegan, 2019). The motivating question is: Why might governments in some political economies be systematically better able to reach stable distributive bargains along both dimensions? Of particular interest to $\mathrm{CPE}$ scholars should be the clear relationship between levels of economic 


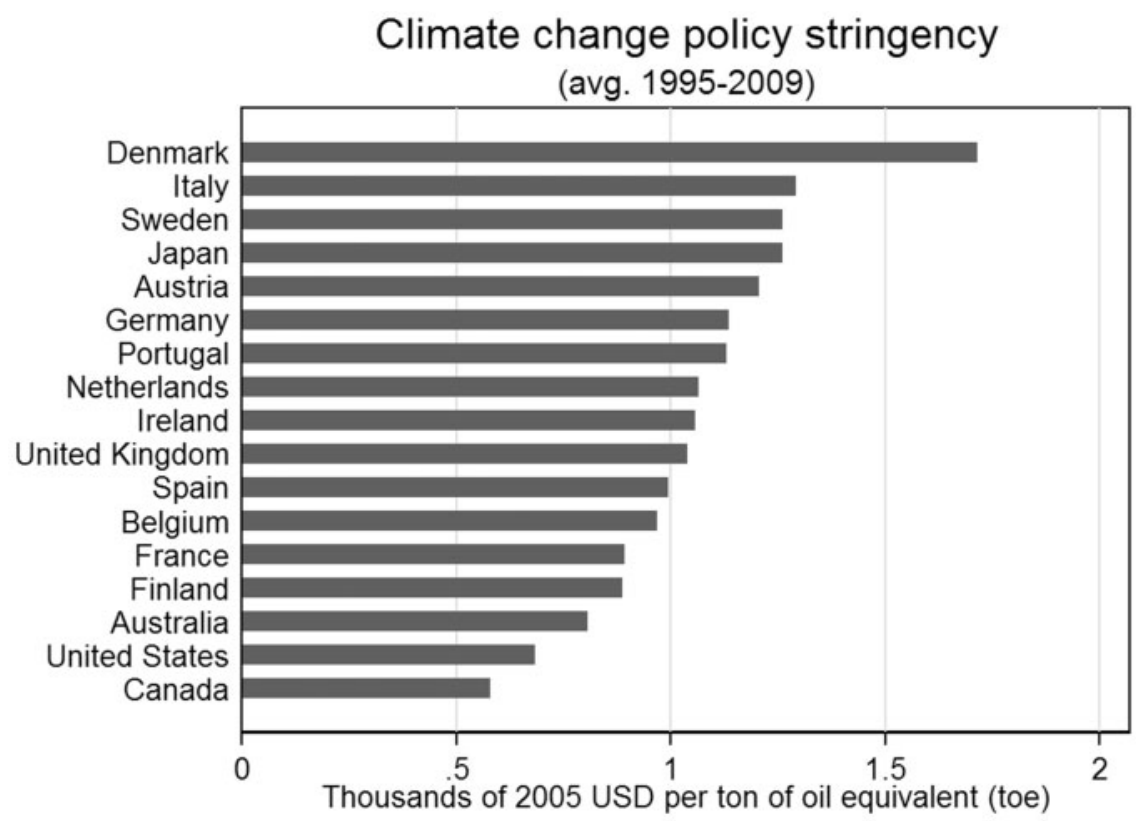

Figure 1 Climate change policy stringency. Notes: Average real 'shadow price' of carbon-based energy weighted by sector output. The measure captures all government policy that changes the price of carbon-intensive inputs for firms and households relative to an 'undistorted' world market price. Conceptually, it provides a measure of the short-term costs imposed on the economy by climate-related policies (see Althammer and Hille, 2016).

coordination and climate policy investment (Figure 2). More (less) coordinated economies have stronger (weaker) climate policies. A major goal of a CPE research agenda should be to examine and explain this relationship. Toward this end, the following section provides a brief snapshot of key CPE research themes to date.

\section{Survey of key research themes}

\subsection{Electoral rules}

Previous CPE research highlights the link between proportional electoral rules, low electoral competitiveness and high consumer prices (e.g. Rogowski and Kayser, 2002), as well as the relationship between electoral safety and long-term policy investment (Jacobs, 2011) and structural economic change (Garrett, 1993). The insight is that only governments with a low risk of losing office can adopt policies that may be unpopular in the short term. Recent studies apply this thinking to the case of climate policy investment. Climate policy is more stringent in countries with more proportional rules (Finnegan, 2019). The proposed causal mechanism is electoral safety. PR rules tend to decrease both electoral competitiveness and clarity of responsibility. Politicians elected under them should therefore enjoy systematically higher levels of electoral safety compared to their counterparts elected under majoritarian 


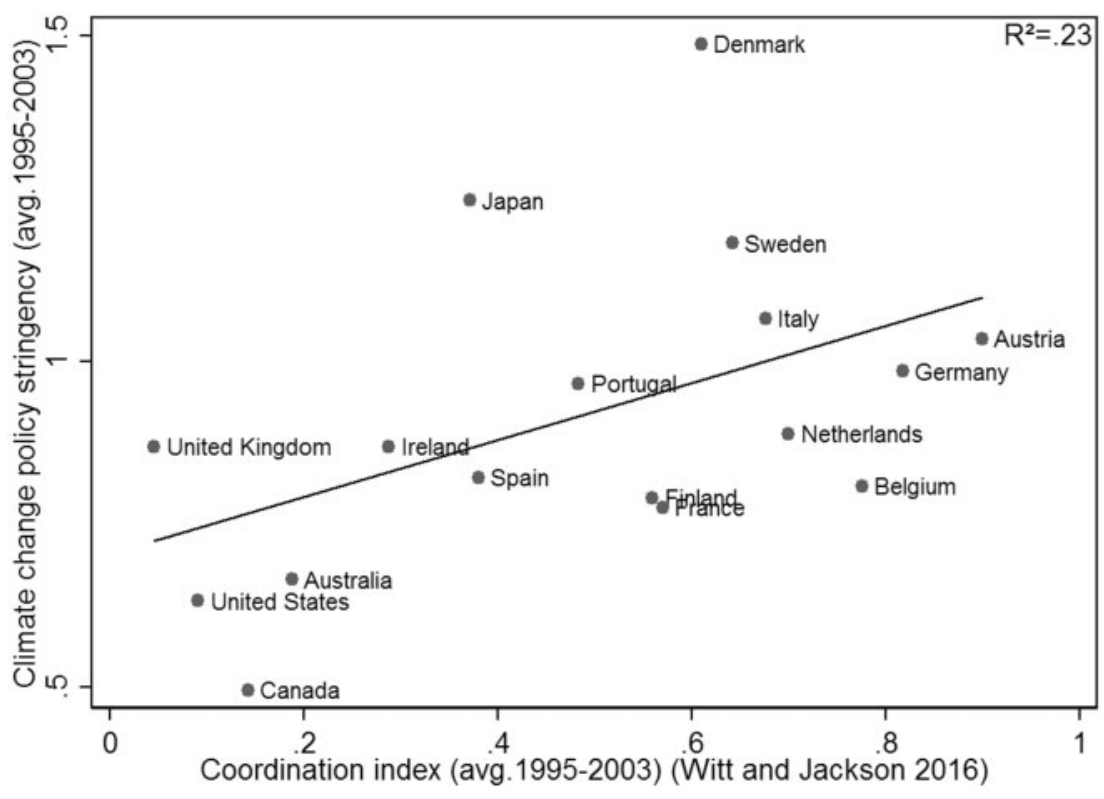

Figure 2 Economic coordination and climate change policy stringency.

rules. Greater electoral safety reduces the political risks of adopting stringent climate policy. Separate work examines the effect of electoral competitiveness in detail and finds that governments refrain from increasing gasoline tax rates when the next election is expected to be tightly contested (Finnegan, 2018). Lipscy (2018) makes complementary arguments about energy conservation policies. Electoral rules influence the extent to which politicians are insulated from diffuse energy consumers. Under majoritarian rules, politicians experience less electoral insulation and are therefore less willing to raise energy prices, decreasing policy stringency. Importantly, this set of work diverges from previous arguments that link PR to climate policy via partisanship, especially green parties (e.g. Harrison and Sundstrom, 2010).

Additional CPE research is needed to further test these arguments. Studies could, for example, build on Lipscy (2018) to examine the effect of changes in electoral rules on other climate-related policies. Similarly, work that analyzes electoral backlash is needed to validate assumptions about the link between voters' material interests and their voting behavior (e.g. Stokes, 2016). Lastly, the relationship between climate policy, partisanship and ideas remains under-theorized. CPE research could build on recent work in this key area (Mildenberger, 2020).

\subsection{Interest group intermediation}

A rich body of CPE literature demonstrates how interest group intermediation, especially corporatism, systematically structures policymaking (e.g. Martin and Swank, 2012). Recent climate-related work extends these findings. Mildenberger (2020) details how corporatism shapes climate policy timing and content across Australia, Norway and the USA 
by structuring how cost-bearing organized groups access policymaking. When carbon-intensive firms and their workers enjoy privileged access (e.g. in Norway), they exercise direct influence over policy design, which can shield them from high compliance costs. Facing lower short-term costs, they are more likely to support government efforts to address climate change. Conversely, in pluralist countries like Australia and the USA, costbearing organized groups are sometimes shut out of policy negotiations, particularly if they are not allied with the governing party. Lacking influence, they are unable to bargain for lower costs. Instead, governments push costs in their direction, causing them to countermobilize and block policy change. Complementary work emphasizes a compensatory mechanism (Finnegan, 2019). Compensation for policy losers is an important ingredient in successful distributive bargains with industry (Jacobs 2011; Lindvall 2017), which are needed if governments are to overcome organized opposition and adopt ambitious longterm climate policy investments. When industry (and workers) can be at least partly compensated, they should be more likely to support the government's agenda. Crucially, granting peak associations for capital and labor privileged access to policy negotiations can reduce the political costs of compensation, namely transaction, administrative and audience costs.

Both sets of work highlight a similar causal process whereby corporatism grants powerful economic actors access and influence over climate policy design, which facilitates a distributive bargain over short-term costs. By doing so, they theoretically situate findings from numerous country case studies that describe the relationship between peak associations, corporatist bargaining and climate policymaking (e.g. Baranzini and Thalmann, 2004; Daugbjerg and Pedersen, 2004; Brand and Pawloff, 2014). However, additional work is needed. It is still unsettled whether and under what conditions granting privileged access to carbon-intensive industries enables them to 'capture' the policy process. Moreover, we know very little about the role of trade unions in climate policymaking. Lastly, climate policy is an excellent case to study the changing nature of state-business relationships across the advanced capitalist countries since 1990 .

The arguments above also predict patterns of public conflict over climate policy. When cost-bearing groups are shut out of negotiations, they should be more likely to counter-mobilize and push distributive conflict into the public arena in an effort, for example, to influence voters. In this way, interest-group intermediation may be linked to voters' climate policy preferences, which could explain the particularly Anglo-Saxon flavor of climate scepticism (e.g. Tranter and Booth, 2015). Further research is needed to theorize and test this relationship.

\subsection{Welfare states}

CPE has a vibrant research agenda on welfare states; however, there is little work that examines the effect of welfare states on climate policymaking. For example, does social protection and low inequality have an effect on voter preferences for costly de-carbonization policies? MacNeil (2016) argues that carbon taxes have repeatedly failed in liberal market economies like Australia, Canada and the USA because it is in these economies that workers have been the least protected from unembedded market forces, leading to squeezed incomes, increasing inequality and declining public services-fertile ground for virulent anti-tax politics that frame climate policy as an additional burden on workers and families. 
This is a promising research area to which CPE scholars are particularly well equipped to contribute.

\subsection{Firm behavior}

Firms are key actors in the context of climate change. However, we know relatively little about the origins of their climate policy preferences. For example, why might otherwise similar firms (across or within counties) have different preferences? Scholars working at the intersection of business and climate change have recently developed typologies and theoretical expectations about the construction of business preferences. Meckling (2015) identifies two factors: distributional effects and regulatory pressure. Firms should support climate policy when benefits outweigh costs and they face high regulatory pressure. Firms oppose policy when costs are high and regulatory pressure is low. When costs and regulatory pressure are high, firms are expected to 'hedge'-seek to reduce their compliance costs, especially relative to competitors. Kelsey (2018) focuses on what firms produce as the driving force behind their material interests. Low-carbon producers are climate policy 'winners' and expected to be supportive, while carbon-intensive producers are 'losers' and expected to oppose policy. Between these two poles lie 'convertible' and 'management' firms. Convertible firms can, in theory, switch to producing clean products (e.g. automakers and utilities). Climate policy involves initial transition costs, but once they shift to low-carbon production they are likely to support policy. However, management firms use carbon-intensive inputs or emit carbon as part of the production process (e.g. steel and cement). They cannot change what they produce, only how. Hence, they are expected to resist policy since it makes production costlier.

These frameworks take seriously the heterogeneity of firm-level preferences over climate policy and offer a foundation for understanding their origins. Empirical evidence is also slowly emerging. In the U.S., nearly all coal companies opposed Obama-era climate policy, while utilities' preferences varied depending on the distribution of costs (Downie, 2017). Furthermore, firms that expected their competitors to face higher costs from U.S. cap-andtrade legislation were more likely to lobby in favor of it (Kennard, 2017). Some evidence, however, appears to contradict expectations. Genovese and Tvinnereim (2018) find that carbon-intensive firms hold a more favorable view of the EU Emissions Trading Scheme, at least in the initial stage of implementation.

A missing piece of this research agenda is an account of how cross-national variation in the institutions that underpin capitalist economies shape firms' preferences. For example, in coordinated market economies (CMEs), firms tend to be organized into encompassing peak associations. This should have a number of effects. Because peak associations bind firms to negotiated decisions, they should decrease the ability of individual companies to reduce their compliance costs vis-à-vis competitors, which renders a strategy of cost shifting less viable. Additionally, peak associations can have a cognitive effect on firm managers (Martin and Swank, 2012). By bringing heterogeneous firms together to deliberate and find internal agreement on a preferred policy, as well as bringing managers into regular contact with policy experts and channeling ideas about the collective benefits of policy change, peak associations can shape firms' perceptions of their own material interests regarding climate change.

Corporate governance should also matter. For example, scholars in CPE and business studies have highlighted how the ownership structure of firms influences their time horizons (e.g. Deeg and Hardie, 2016; Thomsen et al., 2018) When capital is 'patient' firms may be better able to absorb the short-term costs of climate policy. As a result, they may be more 
politically supportive of a de-carbonization agenda. Lastly, CPE arguments predict that variation in capitalist institutions condition how firms innovate (e.g. Hall and Soskice, 2001; Witt and Jackson, 2016). This should also have an effect on firms' preferences, since lowcarbon innovation should structure the short-term costs of climate policy at the firm level.

\section{Institutional complementarities and varieties of de-carbonization}

A key insight of CPE research is that institutions complement one another in both economic and political spheres (e.g. Iversen and Soskice, 2009). Indeed, electoral rules, corporatism, varieties of capitalism and welfare states 'go together' across advanced economies. Moreover, we have stylized models about how consensus-based CMEs should address long-term policy challenges compared to majoritarian LMEs—they should do better (e.g. Martin, 2015). Climate change is a critical case to test these models. Furthermore, an important goal of a CPE research agenda should be to disentangle the effects of complementary (and collinear) institutions. For it is unlikely that any one variable is driving the relationship between economic coordination and climate policy shown in Figure 2. One example of recent research in this vein examines the complementarity between electoral rules and interest group intermediation (Finnegan, 2019). PR rules increase electoral safety, which gives politicians the option to shift short-term costs toward voters. This flexibility opens up crucial room to maneuver in corporatist bargaining with organized groups. Crucially, it enables governments to strike a stable and politically feasible distributive bargain that offers compensation to industry while maintaining a relatively ambitious level of overall stringency by shifting costs onto voters.

Institutional complementarities like these should systematically structure the opportunities for and constraints on long-term climate policymaking across advanced capitalist democracies. As a result, countries should follow distinct, and decipherable, long-term decarbonization trajectories-or varieties of de-carbonization. Systems thinking, which is integral to CPE research, is essential for elucidating the causal processes that underpin national de-carbonization models. Examining, explaining and classifying the logics of different varieties of de-carbonization should serve as the basis for a CPE research agenda on climate change.

\section{Toward a comparative political economy of climate change}

Comparative political economists are particularly well suited to explain variation in climate policy investments across the advanced capitalist world. Yet, the subfield has almost completely ignored this looming policy challenge. This brief article outlined key themes in the emerging CPE of climate change literature, identified gaps and outlined avenues for further research. The hope is that it motivates CPE scholars to take climate change more seriously.

\section{References}

Althammer, W. and Hille, E. (2016) 'Measuring Climate Policy Stringency: A Shadow Price Approach', International Tax and Public Finance, 23, 607-639.

Baranzini, A. and Thalmann, P. (2004) Voluntary Approaches in Climate Policy. Cheltenham, UK, E. Elgar Pub. 
Bernauer, T. (2013) 'Climate Change Politics', Annual Review of Political Science, 16, 421-448. Brand, U. and Pawloff, A. (2014) 'Selectivities at Work: Climate Concerns in the Midst of Corporatist Interests. The Case of Austria', Journal of Environmental Protection, 5, 780-795.

Daugbjerg, C. and Pedersen, A. B. (2004) 'New Policy Ideas and Old Policy Networks: Implementing Green Taxation in Scandinavia', Journal of Public Policy, 24, 219-249.

Deeg, R. and Hardie, I. (2016) 'What Is Patient Capital and Who Supplies It?', Socio-Economic Review, 14, 627-645.

Downie, C. (2017) 'Fighting for King Coal's Crown: Business Actors in the US Coal and Utility Industries', Global Environmental Politics, 17, 21-39.

Finnegan, J. J. (2018) 'Changing Prices in a Changing Climate: Electoral Competitiveness and Fossil Fuel Taxation'. Grantham Research Institute on Climate Change and the Environment Working Paper 307, accessed at http://www.lse.ac.uk/GranthamInstitute/wp-content/uploads/ 2018/10/working-paper-307-Finnegan.pdf on May 28, 2019.

Finnegan, J. J. (2019) 'Institutions, climate change, and the foundations of long-term policymaking'. Grantham Research Institute on Climate Change and the Environment Working Paper 321, accessed at http:/www.lse.ac.uk/GranthamInstitute/wp-content/uploads/2019/04/work ing-paper-321-Finnegan-1.pdf on May 28, 2019.

Garrett, G. (1993) 'The Politics of Structural Change Swedish Social Democracy and Thatcherism in Comparative Perspective', Comparative Political Studies, 25, 521-547.

Genovese, F. and Tvinnereim, E. (2018) 'Who Opposes Climate Regulation? Business Preferences for the European Emission Trading Scheme', Review of International Organizations.

Hall, P. A. and Soskice, D. W. (2001) Varieties of Capitalism: The Institutional Foundations of Comparative Advantage. Oxford, Oxford University Press.

Harrison, K. and Sundstrom, L. M. (2010) Global Commons, Domestic Decisions: The Comparative Politics of Climate Change. Cambridge, MA, MIT Press.

Iversen, T. and Soskice, D. (2009) 'Distribution and Redistribution: The Shadow of the Nineteenth Century', World Politics, 61, 438-486.

Jacobs, A. M. (2011) Governing for the Long Term: Democracy and the Politics of Investment. Cambridge, Cambridge University Press.

Kelsey, N. (2018) 'Industry Type and Environmental Policy: Industry Characteristics Shape the Potential for Policymaking Success in Energy and the Environment', Business and Politics, 20, 615-642.

Kennard, A. (2017) 'Firms' Support for Climate Change Legislation: Industry Competition and the Emergence of Green Lobbies', accessed at https://scholar.princeton.edu/sites/default/files/ kennard/files/greenlobbying_kennard_5.12.17_0.pdf on May 28, 2019.

Lindvall, J. (2017) Reform Capacity. Oxford, Oxford University Press.

Lipscy, P. Y. (2018) 'The Institutional Politics of Energy and Climate Change', accessed at http:// www.lipscy.org/Introduction_lipscyenergyweb.pdf on March 27, 2019.

MacNeil, R. (2016) 'Death and Environmental Taxes: Why Market Environmentalism Fails in Liberal Market Economies', Global Environmental Politics, 16, 21-37.

Martin, C. J. (2015) 'Negotiation and the Micro-Foundations of Institutional Change', In Cooperation and Conflict the Nordic Way: Work, Welfare, and Institutional Change in Scandinavia. Berlin, Germany, De Gruyter.

Martin, C. J. and Swank, D. (2012) The Political Construction of Business Interests: Coordination, Growth, and Equality. Cambridge, Cambridge University Press.

Meckling, J. (2015) 'Oppose, Support, or Hedge? Distributional Effects, Regulatory Pressure, and Business Strategy in Environmental Politics', Global Environmental Politics, 15, 19-37.

Mildenberger, M. (2020) Carbon Captured: How Business and Labor Control Climate Politics. Cambridge, MA, MIT Press. 
Rogowski, R. and Kayser, M. A. (2002) 'Majoritarian Electoral Systems and Consumer Power: Price-Level Evidence from the OECD Countries', American Journal of Political Science, 46, 526-539.

Stokes, L. C. (2016) 'Electoral Backlash against Climate Policy: A Natural Experiment on Retrospective Voting and Local Resistance to Public Policy', American Journal of Political Science, 60, 958-974.

Thomsen, S. Poulsen, T., Børsting, C. and Kuhn, J. (2018) 'Industrial Foundations as Long-Term Owners', Corporate Governance: An International Review, 26, 180-196.

Tranter, B. and Booth, K. (2015) 'Scepticism in a Changing Climate: A Cross-National Study', Global Environmental Change, 33, 154-164.

Witt, M. A. and Jackson, G. (2016) 'Varieties of Capitalism and Institutional Comparative Advantage: A Test and Reinterpretation', Journal of International Business Studies, 47, 778-806.

\title{
Comparative capitalisms and the environment: the ubiquity of markets against the environment?
}

\author{
Maria L. Allen ${ }^{1}$, Matthew M. C. Allen ${ }^{2, *}$, Douglas Cumming ${ }^{3}$ \\ and Sofia Johan ${ }^{3}$
}

\begin{abstract}
${ }^{1}$ Manchester Metropolitan University Business School; ${ }^{2}$ Alliance Manchester Business School, University of Manchester; ${ }^{3}$ College of Business, Florida Atlantic University
\end{abstract}

*Correspondence: Matthew.Allen@manchester.ac.uk

\section{Introduction}

Firms and other market actors wantonly causing potential damage to the environment can take many forms and makes almost daily news. Material gain for the perpetrators is likely to be behind the murder of environmental campaigners who seek to protect land and other natural resources (Global Witness, 2014). Large multinational companies seek to limit national and supranational regulations that would prevent them selling neonicotinoids that have a detrimental impact on bees (PAN Europe, 2018). Fracking occurs in northern England, despite local societal opposition (Perraudin and Pidd, 2018). An energy firm attempts to clear an ancient forest in Germany to mine coal (Business and Human Rights Resource Centre, 2018). Of course, firms and other market actors are not the only ones to damage the environment (Wright, 2010; Movahed, 2016); however, they will, collectively, play an important role in curbing environmental degradation (United Nations Environment Programme, 2018).

The interplay between the state, markets and the environment featured in seminal comparative capitalisms (CC) texts (Johnson, 1982; Polanyi, 2001). For instance, Polanyi argued that capitalism and markets will, if not constrained by society, 'annihilate' the very 
environment that they need to operate (Polanyi, 2001, pp. 3-4). However, it is only recently that comparative-capitalisms research has begun to discuss the links between capitalism and the environment (Wright, 2010; Boyer, 2011; Crouch, 2013; Streeck, 2014; Wood and Wright, 2015). Even fewer studies have assessed the variable impact of different models of capitalism on the environment (Wood and Lane, 2012; Wood, 2015).

We aim to contribute to this emerging literature by assessing the relationship between different institutional domains that are associated with capitalist diversity, on the one hand, and environmental outcomes, on the other. We draw on the arguments and data that form part of a wider project that we are working on that examines the causal links between regulatory changes and environmental outcomes, using time series evidence and panel data (country fixed effects). We provide some exploratory evidence here on the links between key institutions in different types of capitalism and the ability of EU member states to achieve their targets for the percentage of total energy used that comes from renewables as set out in the European Union's 2009 Directive to promote the use of energy from renewable sources in EU member states (European Union, 2009). Our work is, we hope, important not only because the environment is such a globally significant human and social issue, but also because the environment is a relatively neglected area within CC research even though examining the links between capitalism and the environment will help us to understand better the variable ability of different types of capitalism and capitalist firms to limit their impact on the environment.

\section{Theoretical considerations}

Within the comparative capitalisms literature, differences exist on the mechanisms that are highlighted to explain the links between capitalism, firms and environmental outcomes. What we term the Varieties strand of the comparative capitalisms literature tends to highlight how variation in national institutions-rather than capitalism tout court (Wright, 2010; Crouch, 2013; Streeck, 2013)—shapes the developments of firms, markets and socioeconomic outcomes (Whitley, 2010; Allen, 2013; Morgan and Kristensen, 2014). Two institutions are particularly important for our discussion: national financial systems and the role of the government in economic activities (Hall and Soskice, 2001; Wood and Lane, 2012).

The Varieties literature frequently contrasts national financial systems that are likely to increase pressures on senior managers to focus on short-term profits and those that enable managers to take a longer-term perspective (Zysman, 1983; Whitley, 1999; Hall and Soskice, 2001). Of course, actual firms in different countries do not fall neatly into one of these two categories (Goyer, 2011), but this distinction suggests that companies in countries in which the stock market plays a less important role in economic activity may be able to invest more easily in renewable energy sources that have a longer-term pay-out than fossil fuels (Frynas et al., 2017). Another element of financial systems is the role of banks in providing credit to companies. In providing capital to companies, banks establish a direct link between themselves and their debtors and, as a result, can become committed to those debtor companies (Whitley, 1999). Consequently, managers in those companies may be able to take a longer-term approach to the business than they would if institutional investors played a greater role in providing funding (Whitley, 2010), potentially facilitating moves to renewable energy. 
Numerous typologies exist to capture the differential role of the state and the amount of 'risk' the state shares with economic actors in developing new markets (Nölke et al., 2015; Wood and Wright, 2015; Zhang and Zhu, 2018). 'Regulatory states', as an ideal type, provide a 'level playing field' for all firms: they do not intervene directly in company activities and they do not use industrial policy to foster the growth of specific economic sectors (Johnson, 1982). In contrast, 'developmental states' pursue a strategic approach to the economy, aiming to bolster the competitiveness of specific firms or sectors via various means, such as targeted subsidies (Johnson, 1982; Evans, 1989). Of course, in practice, any particular state's role in the economy is likely to vary across different sectors and over time (Keller and Block, 2013).

\section{Data}

Table 1 summarizes the data that covers 27 EU countries for 2012. Our outcome measure is the 'distance to target' of the overall share of energy that comes from renewable sources in each of the EU member states. The 2009 EU directive aimed to promote renewable energy as a share of total energy, which includes energy for electricity, transport, aviation and heating and cooling, for member states, collectively, to $20 \%$ by 2020 ; it enabled each member state to pursue individual targets to reflect its particular context (European Union, 2009). Consequently, some countries have targets greatly above $20 \%$ and other countries have lower ones. We chose to examine each country's 'distance to target'; in other words, the gap between a country's actual percentage of total energy generated from renewable sources and its target. Negative figures mean that the company has not reached its target; positive figures indicate that the country has exceeded its target.

For our explanatory variables, we focus on two key institutions: financial systems and the role of the state. We used two measures to capture corporate governance: stock market capitalization as a percentage of GDP and private credit by deposit money banks and other financial institutions as a percentage of GDP. To capture the role of the state, we include one variable: government $R \& D$ spending on renewable energy sources. To assess any links between these institutions, we assess the correlation between the outcome and our individual explanatory variables. The results are presented in Figures 1-3.

\section{The variable impact of capitalisms on the environment}

The evidence in Figures 1-3 raises a number of important issues for the study of comparative capitalisms and the environment. First, different types of capitalism have a variable impact on the environment. There is a strong correlation between the role of the stock market in overall economic activity and the ability of countries to meet their renewable-energy targets that they set out in the EU's 2009 Directive: the lower the value of stock-market capitalization as a percentage of GDP, the more likely the country was to meet or exceed its target in 2012. This strong correlation suggests that there is a need to understand the mechanisms by which governments are able to meet environmental targets. The greater prevalence of stockmarket listed firms in an economy would appear to hinder policymakers' efforts to improve environmental outcomes. As Sweden appears to be an outlier in Figure 1(a), we excluded it from a further correlation that we conducted and show in Figure 1(b). The magnitude of the Pearson correlation coefficient and its statistical significance increased, indicating that (a) 
Table 1 Summary statistics 2012

\begin{tabular}{|c|c|c|c|c|c|c|}
\hline Source & $\begin{array}{l}\text { Percentage } \\
\text { of total } \\
\text { energy from } \\
\text { renewable } \\
\text { sources } \\
\text { Eurostat }\end{array}$ & $\begin{array}{c}\text { EU } 2009 \\
\text { Directive } \\
\text { Target } \\
\text { for } 2020\end{array}$ & $\begin{array}{c}\text { 'Distance' } \\
\text { to } 2020 \\
\text { Target }\end{array}$ & $\begin{array}{c}\text { Private Credit } \\
\text { by Deposit } \\
\text { Money Banks and } \\
\text { other Financial } \\
\text { Institutions to } \\
\text { GDP (\%) } \\
\text { World Bank }\end{array}$ & $\begin{array}{c}\text { Stock Market } \\
\text { Capitalization } \\
\text { to GDP }(\%)\end{array}$ & $\begin{array}{c}\text { Government } \\
\text { R\&D on } \\
\text { Renewable } \\
\text { Energy, } \\
\% \text { of GDP } \\
\text { International } \\
\text { Energy } \\
\text { Association }\end{array}$ \\
\hline \multicolumn{7}{|l|}{ Member State } \\
\hline Austria & 31.41 & 34 & -2.59 & 94 & 23 & 0.008 \\
\hline Belgium & 7.18 & 13 & -5.82 & 54 & 52 & 0.004 \\
\hline Bulgaria & 16.05 & 16 & 0.05 & 66 & 14 & 0 \\
\hline Cyprus & 6.77 & 13 & -6.23 & 248 & 9 & 0 \\
\hline Czech Republic & 12.83 & 13 & -0.17 & 50 & 18 & 0.005 \\
\hline Denmark & 25.75 & 30 & -4.25 & 187 & 61 & 0.016 \\
\hline Estonia & 25.81 & 25 & 0.81 & 75 & 8 & 0.001 \\
\hline Finland & 34.41 & 38 & -3.59 & 91 & 57 & 0.019 \\
\hline France & 13.40 & 23 & -9.60 & 96 & 61 & 0.006 \\
\hline Germany & 12.09 & 18 & -5.91 & 84 & 36 & 0.009 \\
\hline Greece & 13.45 & 18 & -4.55 & 121 & 15 & - \\
\hline Hungary & 15.52 & 13 & 2.52 & 56 & 15 & 0.004 \\
\hline Ireland & 7.16 & 16 & -8.84 & 113 & 47 & 0.005 \\
\hline Italy & 15.44 & 17 & -1.56 & 96 & 21 & 0.004 \\
\hline Latvia & 35.73 & 40 & -4.27 & 69 & 4 & - \\
\hline Lithuania & 21.44 & 23 & -1.56 & 47 & 9 & - \\
\hline Luxembourg & 3.13 & 11 & -7.87 & 87 & 119 & 0.009 \\
\hline Malta & 2.83 & 10 & -7.17 & 113 & 37 & - \\
\hline Netherlands & 4.72 & 14 & -9.28 & 118 & 73 & 0.013 \\
\hline Poland & 10.90 & 15 & -4.10 & 51 & 30 & 0.004 \\
\hline Portugal & 24.60 & 31 & -6.40 & 159 & 28 & 0.001 \\
\hline Romania & 22.84 & 24 & -1.16 & 44 & 10 & - \\
\hline Slovak Republic & 10.42 & 14 & -3.58 & 46 & 5 & 0.018 \\
\hline Slovenia & 20.82 & 25 & -4.18 & 82 & 13 & - \\
\hline Spain & 14.30 & 20 & -5.70 & 161 & 72 & 0.002 \\
\hline Sweden & 51.14 & 49 & 2.14 & 128 & 93 & 0.008 \\
\hline United Kingdom & 4.57 & 15 & -10.43 & 168 & 112 & 0.003 \\
\hline
\end{tabular}

there is a strong connection between stock market capitalization and the ability of member states to reach their renewable-energy objectives and (b) the types of shareholders and their degree of ownership may play a role in explaining important outcomes (Schnyder, 2012).

Second, our measure of private financing to firms is also statistically significantly correlated to our outcome measure, suggesting a moderate link between private credit and progress towards national renewable energy goals. The greater the private credit provided by banks as a percentage of gross domestic product, the further the country is from meeting its 


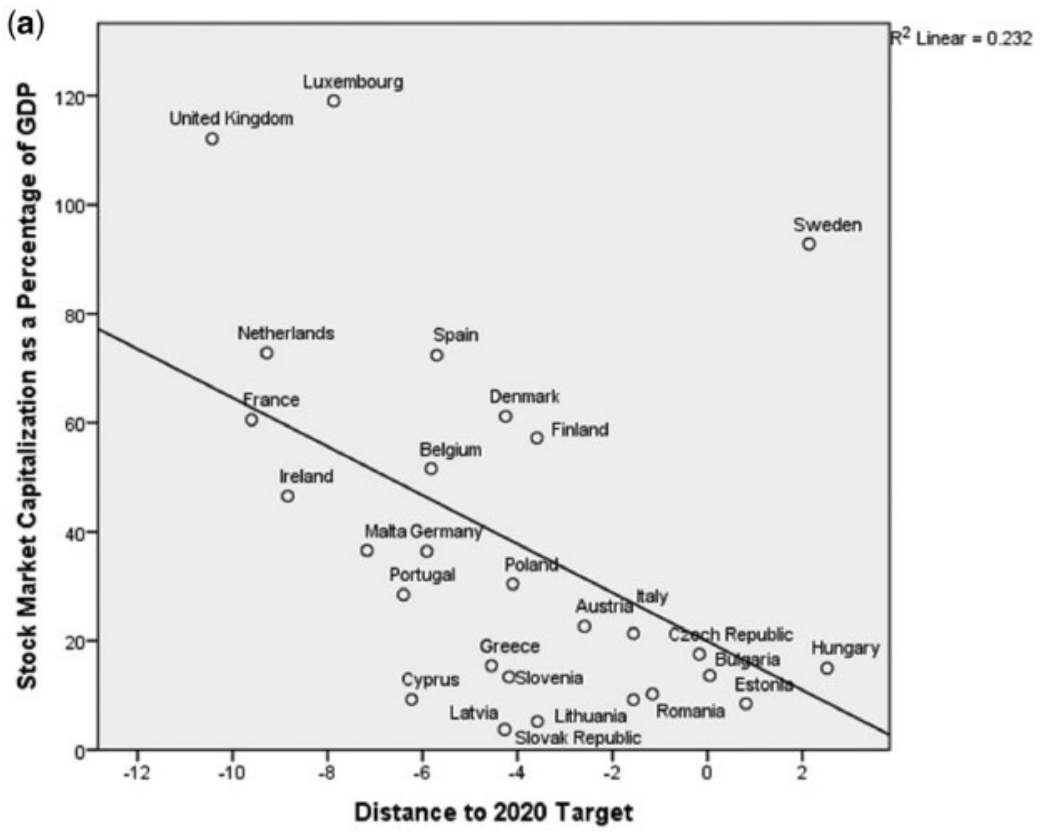

Pearson Correlation: -.482*; significant at the 0.05 level (2-tailed).

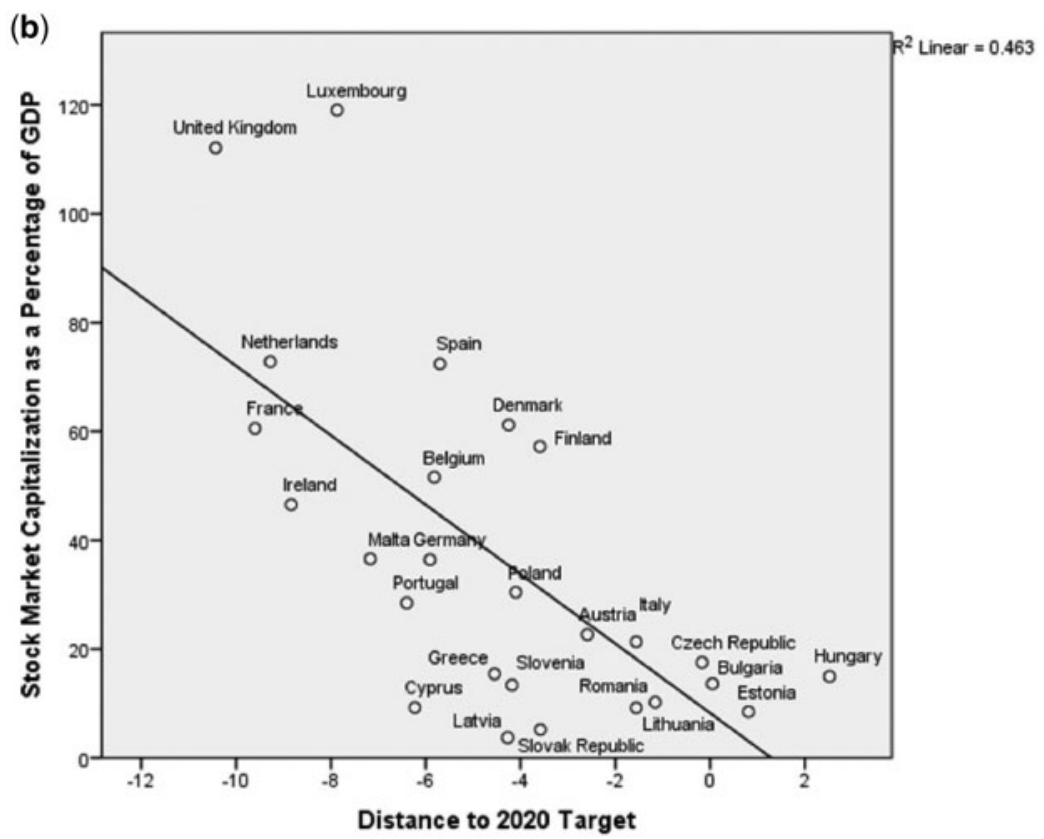

Pearson Correlation: -.681**; significant at the 0.01 level (2-tailed).

Figure 1 (a) Stock market capitalization and distance to 2020 target, as at 2012. Pearson correlation: $-0.482 *$; significant at the 0.05 level (two-tailed). (b) Stock market capitalization and distance to 2020 target, as at 2012 without Sweden. Pearson correlation: $-0.681 ;{ }^{* *}$ significant at the 0.01 level (two-tailed). 


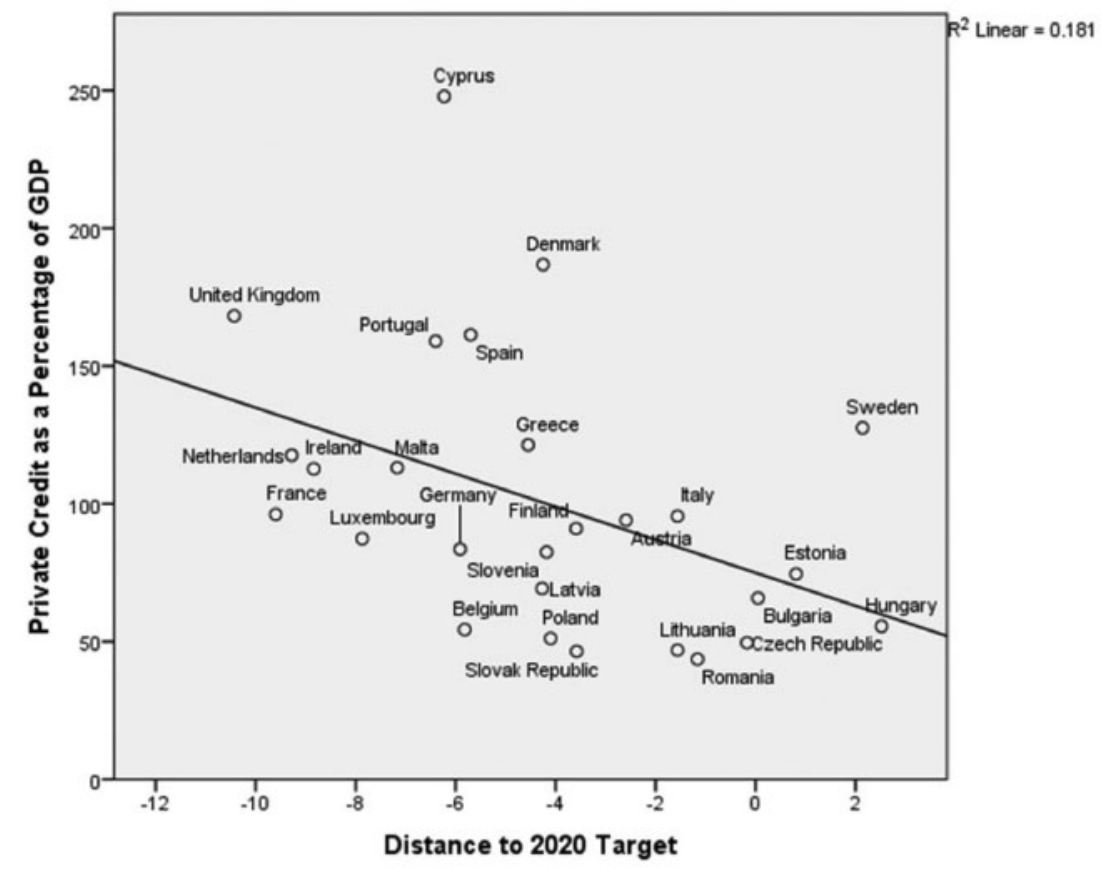

Pearson Correlation: -.425*; significant at the 0.05 level (2-tailed).

Figure 2 Private credit by deposit money banks and other financial institutions \% GDP against distance to 2020 target as at 2012. Pearson correlation: $-0.425^{*}$; significant at the 0.05 level (two-tailed).

renewable-energy targets. Possible reasons for this paradoxical finding are that (a) our measure of private finance may fail to adequately capture venture capital funding for companies that develop renewable-energy technologies (Cumming and Schwienbacher, 2018) as well as the role of corporations that self-fund large scale electricity-generating facilities that rely on renewable sources (Kraemer, 2016) and (b) the prospect of short-term returns, which often prove to be illusory, from fracking and hydrocarbons compared to investments in renewable energy projects (Wood, 2015).

Third and somewhat paradoxically, the evidence that we present here on the role of the state suggests that there is no link between public R\&D spending on renewable energy and the share of energy from renewables. This result may indicate that the state plays a complex role in this area. For instance, the state's ability to foster less damaging environmental outcomes may stem primarily from policies, such as subsidies for electricity generated from renewable-energy sources, rather than from directly promoting technology development. Additionally, other institutional supports required for renewable-energy technologies to succeed, such as a skilled workforce and knowledgeable investors, may be 'missing' (Allen, 2013). A further explanation that our data do not capture is that governments in some of the most liberalized economies have, in relation to hydrocarbons, adopted statist policies, increasingly subsidizing and supporting the oil and gas industry (Wood and Wright, 2015), potentially at the expense of renewable energy. 


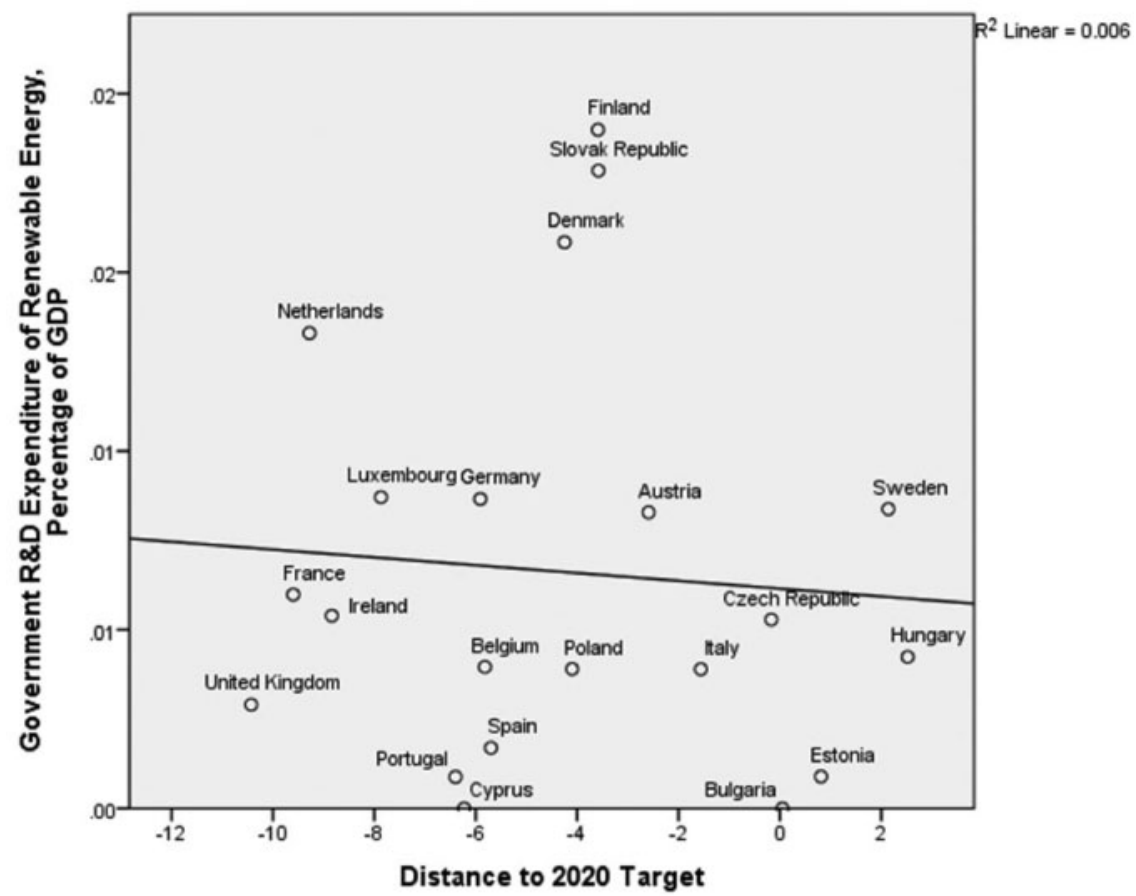

Pearson Correlation:-.075; not significant.

Figure 3 Government R\&D expenditure on renewable energy as percentage of GDP and distance to 2020 target, as at 2012. Pearson correlation: -0.075 ; not significant.

Overall, our analysis demonstrates the importance of adopting an institutional perspective to explain differences in environmental outcomes. The role of stock markets, the types of shareholders and their levels of ownership and control would appear to be particularly important. However, we have merely scratched the surface on the links between different types of capitalism and the environment. By doing so, we hope that this short paper helps to stimulate further analyses. Other important areas that we were not able to examine include firms' institutionally conditioned strategic priorities, societal pressures, the role of labormarket institutions, state subsidies to different energy sources, wider environmental policies, the consistency of governmental environmental policy, more general business regulations that may influence investments in power stations that rely on renewable energy, and the potential complementarities (both mutually supporting and deficiency-overcoming ones) between and within these areas.

\section{References}

Allen, M. M. C. (2013) 'Comparative Capitalisms and the Institutional Embeddedness of Innovative Capabilities', Socio-Economic Review, 11, 771-794.

Boyer, R. (2011) ‘Are There Laws of Motion of Capitalism?’, Socio-Economic Review, 9, 59-81. 
Business \& Human Rights Resource Centre. (2018) 'Germany: Environmentalists Arrested in Dispute over RWE's Plans to Clear Forest to Mine Brown Coal', accessed at https://www.busi ness-humanrights.org/en/germany-environmentalists-arrested-in-dispute-over-rwes-plans-toclear-forest-to-mine-brown-coal on November 15, 2018.

Crouch, C. (2013) Making Capitalism Fit for Society, Cambridge, Polity Press.

Cumming, D. J. and Schwienbacher, A. (2018) 'Fintech Venture Capital', Corporate Governance: An International Review, 26, 374-389.

European Union. (2009) Directive 2009/28/EC of the European Parliament and of the Council of 23 April 2009, Brussels, 140.

Evans, P. B. (1989) 'Predatory, Developmental, and Other Apparatuses: A Comparative Political Economy Perspective on the Third World State', Sociological Forum, 4, 561-587.

Frynas, J. G., Wood, G. and Hinks, T. (2017) 'The Resource Curse without Natural Resources: Expectations of Resource Booms and Their Impact', African Affairs, 116, 233-260.

Global Witness. (2014) Deadly Environment: The Dramatic Rise in Killings of Environmental and Land Defenders, London, Global Witness Limited.

Goyer, M. (2011) Contingent Capital: Short-Term Investors and the Evolution of Corporate Governance in France and Germany, Oxford, Oxford University Press.

Hall, P. A. and Soskice, D. (2001) 'An Introduction to Varieties of Capitalism', In Hall, P. A. and Soskice, D. (eds) Varieties of Capitalism: The Institutional Foundations of Comparative Advantage, pp. 1-56. Oxford, Oxford University Press.

Johnson, C. (1982) MITI and the Japanese Miracle: The Growth of Industrial Policy, 1925-75. Stanford, CA, Stanford University Press.

Keller, M. R. and Block, F. (2013) 'Explaining the Transformation in the US Innovation System: The Impact of a Small Government Program', Socio-Economic Review, 11, 629-656.

Kraemer, S. (2016) '\$100 Billion Now Building Indian Clean Energy', Renewable Energy World, accessed at https://www.renewableenergyworld.com/articles/2016/08/100-billion-now-build ing-indian-clean-energy.html on November 16, 2018.

Morgan, G. and Kristensen, P. H. (2014) 'The Comparative Analysis of Capitalism and the Study of Organizations'. In Adler, P., du Gay, P., Morgan, G., and Reed, M. (eds) The Oxford Handbook of Sociology, Social Theory, and Organization Studies: Contemporary Currents, pp. 220-245.

Movahed, M. (2016) 'Does Capitalism Have to Be Bad for the Environment?', World Economic Forum, accessed at https://www.weforum.org/agenda/2016/02/does-capitalism-have-to-be-badfor-the-environment/ on November 16, 2018.

Nölke, A., ten Brink, T., Claar, S. and May, C. (2015) 'Domestic Structures, Foreign Economic Policies and Global Economic Order: Implications from the Rise of Large Emerging Economies', European Journal of International Relations, 21, 538-567.

PAN Europe. (2018) 'Neonicotinoids: The European Court of Justice Upholds the 2013 Decision to Impose Restrictions on Their Use', accessed at https:/www.pan-europe.info/press-releases/ 2018/05/neonicotinoids-european-court-justice-upholds-2013-decision-impose on November 15, 2018.

Perraudin, F. and Pidd, H. (2018) 'Anger and Blockades as Fracking Starts in UK for First Time since 2011', The Guardian, accessed at https:/www.theguardian.com/environment/2018/oct/ 15/fracking-protesters-blockade-cuadrilla-site-where-uk-work-due-to-restart on November 15, 2018.

Polanyi, K. (2001) The Great Transformation: The Political and Economic Origins of Our Time, Boston, Beacon Press.

Schnyder, G. (2012) 'Varieties of Insider Corporate Governance: The Determinants of Business Preferences and Corporate Governance Reform in The Netherlands, Sweden and Switzerland', Journal of European Public Policy, 19, 1434-1451. 
Streeck, W. (2013) Gekaufte Zeit: Die Vertagte Krise Des Demokratischen Kapitalismus, Berlin, Suhrkamp.

Streeck, W. (2014) 'Taking Crisis Seriously: Capitalism on Its Way Out', Stato e Mercato, 45-67.

United Nations Environment Programme. (2018) UN Environment Annual Report 2017. Nairobi, UNEP.

Whitley, R. (1999) Divergent Capitalisms: The Social Structuring and Change of Business Systems, Oxford, Oxford University Press.

Whitley, R. (2010) 'The Institutional Construction of Firms', In Morgan, G., Campbell, J. L., Crouch, C., Pedersen, O. K. and Whitley, R. (eds) The Oxford Handbook of Comparative Institutional Analysis, Oxford, Oxford University Press, pp. 453-495.

Wood, G. (2015) 'Structural Crisis and Transitions: Present Issues and Potential Future Trajectories', Journal of Comparative Economic Studies, 10, 55-68.

Wood, G. and Lane, C. (2012) 'Institutions, Change, and Diversity'. In Lane, C. and Wood, G. (eds) Capitalist Diversity and Diversity within Capitalism, pp. 1-31. Abingdon, Routledge.

Wood, G. and Wright, M. (2015) 'Corporations and New Statism: Trends and Research Priorities', Academy of Management Perspectives, 29, 271-286.

Wright, E. O. (2010) Envisioning Real Utopias, London, Verso.

Zhang, X. and Zhu, T. (2018) 'Understanding Business-Government Relations in China: Changes, Causes and Consequences'. In Zhang, X. and Zhu, T. (eds) Business, Government and Economic Institutions in China, pp. 3-46. Basingstoke, Palgrave Macmillan.

Zysman, J. (1983) Governments, Markets, and Growth: Financial Systems and the Politics of Industrial Change, Ithaca, NY, Cornell University Press.

\title{
Increasing divergence of energy supply? Comparative study of German and Japanese wind power
}

\author{
Manuel Nicklich ${ }^{1, *}$ and Takahiro Endo ${ }^{2}$ \\ ${ }^{1}$ Institut für Soziologie, FAU Nürnberg-Erlangen; ${ }^{2}$ Hitotsubashi University \\ *Correspondence: manuel.nicklich@fau.de
}

\section{Introduction}

The Fukushima disaster of 2011 has changed the global perspective on renewable energies. However, the transition to renewables has been mixed. While the Japanese Government considered a 'green future' following the catastrophe (Barrett, 2012), a drastic shift towards renewables has yet to be seen. In fact, Japan's reliance on coal and liquefied natural gas (LNG) has increased (Normile, 2018): together they generated almost $70 \%$ of the energy supply in 2017 (coal 30.4\%, LNG 38.7\%). In contrast, Germany radically shifted its energy policy away from nuclear power towards renewables immediately after the catastrophe.

Environmental problems are, of course, a global issue (Goworek et al., 2018). As economic activities increasingly cross national borders, they affect the environment on a global scale. Given these contradictory notions of convergence/divergence (i.e. the contrasting 
response to catastrophe that may indicate divergence and the globalizing environmental problem that may suggest convergence), an intriguing question is: Do globalization and globally perceived occurrences of environmental problems lead to a convergence of energy supply? If not, what explains such non-convergence?

Globalization is often associated with the convergence/divergence debate, especially in terms of environmental policy (Jörgens et al., 2014). Convergence indicates that a practice becomes increasingly similar across countries (Dresser, 2001; Khanna and Palepu, 2004). Divergence means that, although globalization provides cognitive-normative templates for 'standard' practice, actors who are conditioned by the local historical context tailor such templates, resulting in continuous or even increasing divergence of the very practice (Bamber et al., 2004; Yoshikawa et al., 2007; Schrecker et al., 2008).

To answer our questions, we empirically examine the fields of German and Japanese wind power with a particular focus on Greenpeace as a major player in the international discourse on renewable energy. Wind power, in addition to solar, represents a major source of 'green' renewables. More importantly, wind power is a telling example of non-convergence in energy use: high in Germany (16\% of electricity generated in 2017) and low in Japan $(0.6 \%$ in 2017).

Decisions concerning the energy mix in a country involve a complex interplay of 'various factors'. This interplay conditions the mixture of energy supply in a country and results in either convergence or, despite pressure to adopt an influential template such as increasing awareness of sustainability typically represented in the ratification of sustainable development goals (SDGs) and the Fukushima catastrophe, divergence. In order to deal with the 'various factors', we draw on the concepts of relational distance and transformational skills to analyze forces leading to the divergence of wind power usage in our two focal countries. Relational distance, here, means relative distance between actors that can be measured by referring to cognitive-normative templates as well as rules of resource use and access (Ibert, 2010). Social skills basically indicate actors' skills to convince other actors to collaborate or change their opinion and behavior.

In our comparative research, we investigated a broad range of actors in the German and Japanese fields of wind power generation (Nicklich and Sydow, 2018). However, due to the limitations of space, we focus on one particular actor, Greenpeace, as a representative of international environmental NGOs, in the remainder of this article.

\section{Conceptualizing relational distance and transformation skills}

Building on insights from Fligstein and McAdam's (2012) theory of fields, we argue that actors may share views, but not necessarily arrive at a consensus on a phenomenon, such as climate change (Carvalho, 2007; O’Brien et al., 2007). According to Fligstein and McAdam, this is mainly because actors' interests and power positions vary. Nevertheless, the essence of difference in actors' interests needs to be more explicitly articulated. Stemming from the discipline of economic geography, the idea of relational distance tries to capture some of these differences. In contrast to physical distance, which describes the position of organizations or other entities in relation to other places, sites or territories in space, Ibert (2010, p. 188) states: 'relational distance contrasts the units of analysis in terms of their dissimilar places within systems of cultural norms. Distance here specifies the degree in which publicly shared values, worldviews or interpretation schemes diverge'. 
Table 1. Summary of comparative analysis

\begin{tabular}{|c|c|c|}
\hline & German case & Japanese case \\
\hline Relational distance & $\begin{array}{l}\text { - Close between NGOs and } \\
\text { Green Party } \\
\text { - Close between NGOs and } \\
\text { corporate new entrants }\end{array}$ & $\begin{array}{l}\text { - Some connection between } \\
\text { NGOs and small left-wing party } \\
\text { - Not close between NGOs and } \\
\text { corporate actors (few corporate } \\
\text { new entrants) }\end{array}$ \\
\hline $\begin{array}{l}\text { Transformational } \\
\text { skills }\end{array}$ & $\begin{array}{l}\text { Exercised and developed social } \\
\text { skill over time, expanding the } \\
\text { wind power field }\end{array}$ & $\begin{array}{l}\text { - Faced with limitation in developing } \\
\text { social skill, poor contribution for } \\
\text { expanding the wind power field }\end{array}$ \\
\hline
\end{tabular}

Source: Own creation.

Dynamics in this relational distance are strongly connected to the organizational actors' skills and their practices of dealing with certain issues (Fligstein, 1999). Social skills allow the flexible accommodation of various interests and let actors collaborate in a way that may result in the creation, reproduction or disruption of structures. Transformation skills, then, are those social skills of an individual or collective actor that are able to alter the relational distance. The alternation of relational distance results in either the alignment or dispersion of the cognitive-normative template and resource usage among the actors involved. Especially in convulsive moments, the role of social skills in fields seems to be decisive (Fligstein and McAdam, 2012, p. 54). However, once resource use and access have been established, the status quo accords stability to power relations and thus make change difficult (Jackson, 2010). In relation to our empirical phenomena, the Fukushima catastrophe can be conceptualized as a triggering event, which often provides the opportunities for skilled actors or 'knowledgeable agents' (Giddens, 1984) to take action towards a transformation in or of the field. When explicated, these skills would include the capacity to persuade other actors (Green Jr, 2004; Suddaby and Greenwood, 2005), create benefits for other actors (Hitt et al., 2011) and build a coalition with relevant actors (Fligstein, 2001; Maguire et al., 2004).

\section{Brief illustration of German and Japanese wind power fields}

To examine the central question of our project, the convergence/divergence of energy supply, we briefly sketch the role of Greenpeace in the German and Japanese energy sectors. The emphasis will be on contrasting the role played by this NGO in the two economies. We refer to blog entries as well as qualitative interviews with different actors and examine their involvement. Looking at the status of wind energy, one has to say that in Germany the share of conventional power today is still about $70 \%$. However, during the last decade, the share of renewable energy generated has increased significantly. In 2015, the share of all renewables was $31.5 \%$ and share of wind power $12.3 \%$. By contrast, in the same year, renewables (biomass, geothermal and hydropower, photovoltaics and last but not least wind power) represented only $14.5 \%$ of energy production in Japan. The share of wind power in Japan in 2015 was even as low as $0.5 \%$. What explains these very different responses to the Fukushima disaster? 


\section{Relational distance and transformation skills}

Drawing on our research that included 75 problem-centered interviews (Witzel and Reiter, 2012) with representatives of energy corporations, state actors and non-governmental actors and secondary documents (Heaton, 2008) such as blog posts by Greenpeace for example, we argue that relational distance concerning corporate actors is significantly different between German and Japanese cases. While the German case is characterized by a significant relational distance between firms generating non-renewables and renewable-energy firms, the Japanese case is not. Table 1 summarizes this contrasting difference in relational distance and transformation skills.

In Germany, energy transition towards renewables (solar and wind in particular) has been pushed forward by a coalition of NGOs and the Green Party, and has opened up important new fields of business for new entrants, including small and medium-sized enterprises. This means that a diverse range of organizational actors can be seen as drivers of energy transition in this country. This can be illustrated by examining Greenpeace and its relationship to other relevant actors. While Greenpeace has always heavily criticized the practices of traditional energy generators, in its publications, it gives renewable-energy firms, including those related to wind power, the possibility to articulate their ideas and speak about their products. Moreover, the Green Party's membership of the governing coalition in the Federal Government between 1998 and 2005 enabled Greenpeace to connect to politics more easily. In sum, in the German case the relational distance between new entrants and these actors was and continues to be low, whereas among the corporate new entrants and traditional energy suppliers the relational distance was rather high. Given this constellation, Greenpeace in Germany had various opportunities to use transformation skills to induce cooperation among relevant organizational actors. Furthermore, through 'learning by doing', Greenpeace developed the ability to build coalitions with renewable generators, namely windpower firms against the non-renewable energy suppliers. This ability is demonstrated not least by joint activities regarding the energy transition, resulting, for example, in joint studies by Greenpeace and employer associations for wind energy (Greenpeace Energy, 2012; Jansen and Sager-Klauß, 2017). These joint studies, however, illustrate not only the possibility to build coalitions, but also-content-wise- to show skills of persuasion and the establishment or demonstration of benefits. As they look at the 'real price' of energy generation in a comparative and comprehensive way (wind energy vs. traditional forms; especially nuclear and fossil), this practice delivered a scientifically legitimated and economically oriented argument for the energy transition. By including the follow-up costs of fossil and nuclear power, the studies demonstrate, that is, show and create, the benefits of wind energy for state and society.

In the Japanese field, environmental NGOs and a small left-wing party, to some extent, share a cognitive-normative template. For example, Greenpeace Japan as well as the Social Democratic Party Japan have strongly criticized the reactivation of nuclear power plants, but with very limited effects. Furthermore, there are some other environmental NGOs that clearly oppose the reactivation of nuclear power plants; however, they have rarely collaborated with corporate actors. This is partly because Japan has not witnessed the emergence of 'real' renewable energy generators, which are relatively free from the intervention of large non-renewable energy generators. Even after the Fukushima catastrophe, such 'real', independent renewable generators have not grown significantly. Instead, non-renewable energy generators used their subsidiaries or joint ventures in dealing with wind power generation. These subsidiaries and joint ventures do not actively collaborate with NGOs and political 
parties that pursue an anti-nuclear ideology. In a nutshell, with regard to the Japanese case the relational distance between NGOs and political parties does not significantly differ from the German case. However, a crucial difference lies in the role or existence of renewable energy firms that keep a significant distance from generators of traditional energy. Given this constellation, Greenpeace Japan faced difficulty in actually exercising and developing transformation skills, particularly when it came to inducing co-operation from corporate actors.

\section{Conclusions}

In this article, we intend to provide insights into the divergence of the energy mix across two countries that are typically considered as belonging to the category of coordinated market economies (Soskice, 1999). Our analysis concentrates on the interplay between relational distance and transformational skills. The German case indicates that the close relationship between NGOs and renewable energy generators allowed both types of actors to develop social skills. In contrast, in Japan, NGOs and corporate actors were far-distanced, since they did not witness the emergence of new entrants focusing on the generation of renewable energy. Instead, traditional energy suppliers stayed in control of the (non-transformative) process. In conclusion, one can say that despite structural similarities between Germany and Japan, we can witness quite different transformational practices, such as, for example, the construction of positive associations like technical efficiency, economic growth and employment regarding renewable energy by the current government or trade unions, thereby changing the cognitive-normative template. As established institutional rules of resource use and access by dominant incumbent actors accorded stability in the actor constellation (Jackson, 2010), change seems to be slow in Japan despite the triggering event of Fukushima. In contrast, the Fukushima event accelerated the shortening of this distance between these two dramatically in the case of - far away-Germany.

This argumentation can only be a start in answering the question of globally perceived (non) convergence of energy use. Eventually, we need further examination of the two fields. More precisely, particularly the process concerning the question of how the relational distance as well as transformational skills unfolds and changes over time should be part of this examination. This unfolding and change, however, is strongly connected to the issue of how actors-non-renewable energy generators and (non)corporate new entrants-make sense of the past. In consequence, further research has to take the role of collective memory into account (Coraiola et al., 2018), which seems to mediate transformation skills and relational distance.

\section{References}

Bamber, G. J., Lansbury, R. D. and Wailes, N. (eds) (2004) International and Comparative Employment Relations. Thousand Oaks, CA: Sage.

Barrett, B. (2012) 'After the Nuclear Disaster, Japan Considers a Green Future', Solutions Journal, 3, 99-103.

Carvalho, A. (2007) 'Ideological Cultures and Media Discourses on Scientific Knowledge: Re-Reading News on Climate Change', Public Understanding of Science, 16, 223-243.

Coraiola, D., Suddaby, R. and Foster, W. M. (2018) 'Organizational Fields as Mnemonic Communities'. In Glückler J., Suddaby R. and Lenz R. (eds) Knowledge and Institutions, pp. 45-68. Springer.

Fligstein, N. (1999) Fields, Power and Social Skill: A Critical Analysis of the New Institutionalisms. Berkeley, CA, Center for Culture, Organizations and Politics. 
Fligstein, N. (2001) 'Social Skill and the Theory of Fields', Sociological Theory, 19, 105-125. Fligstein, N. and McAdam, D. (2012) A Theory of Fields. Oxford, Oxford University Press.

Giddens, A. (1984) The Constitution of Society. Outline of the Theory of Structuration. Berkeley, Polity Press.

Goworek, H., Land, C., Burt, G., Zundel, M., Saren, M., Parker, M. and Lambe, B., (2018) 'Scaling sustainability: Regulation and resilience in managerial responses to climate change', British Journal of Management, 29, 209-219.

Green, S. E, Jr., (2004) 'A Rhetorical Theory of Diffusion', Academy of Management Review, 29, 653-669.

Greenpeace Energy. (2012) 'Was Strom wirklich kostet', accessed at https://www.greenpeace-energy. de/fileadmin/docs/publikationen/Studien/Stromkostenstudie_Greenpeace_Energy_BWE.pdf on May 28, 2019.

Heaton, J. (2008) 'Secondary Analysis of Qualitative Data: An Overview', Historical Social Research/Historische Sozialforschung 33, 33-45.

Hitt, M. A., Ireland, R. D., Sirmon, D. G., and Trahms, C. A. (2011) 'Strategic Entrepreneurship: Creating Value for Individuals, Organizations, and Society', Academy of Management Perspectives, 25, 57-75.

Ibert, O. (2010) 'Relational Distance: Sociocultural and Time-Spatial Tensions in Innovation Practices', Environment and Planning A: Economy and Space, 42, 187-204.

Jackson, G. (2010) 'Actors and Institutions'. In Morgan, G., Campbell, J., Crouch, C., Pedersen, O. K. and Whitley, R. (eds) The Oxford Handbook of Comparative Institutional Analysis, pp. 63-86. Oxford, Oxford University Press.

Jansen, M. and Sager-Klauß, C. (2017) 'Das Gekoppelte Energiesystem', accessed at https://www. bee-ev.de/fileadmin/Publikationen/Studien/20171215_StudieBEE_SektorenKopplung_FINAL. PDF on May 28, 2019.

Jörgens, H., Lenschow, A. and Liefferink, D. (eds) (2014) Understanding Environmental Policy Convergence: The Power of Words, Rules and Money. Cambridge, Cambridge University Press.

Khanna, T. and Palepu, K. G. (2004) 'Globalization and Convergence in Corporate Governance: Evidence from Infosys and the Indian Software Industry', Journal of International Business Studies, 35, 484-507.

Nicklich, M. and Sydow, J. (2018) Organization of Value Creation and Work in the Japanese Wind Power Industry: Studying Organizational Diversity in Face of Institutional Change. INCAS Discussion Paper 2ß18\#01, available at https://incas.hypotheses.org/files/2018/01/ INCAS-DP-SERIES_2018_01.pdf on May 29, 2019.

Normile, D. (2018) 'Bucking Global Trends, Japan Again Embraces Coal Power', Science, 360, 476.

O'Brien, K., et al. (2007) 'Why Different Interpretations of Vulnerability Matter in Climate Change Discourses', Climate Policy, 7, 73-88.

Schrecker, T., Labonté, R. and De Vogli, R. (2008) 'Globalisation and Health: The Need for a Global Vision', Lancet, 372, 1670-1676.

Soskice, D. (1999) 'Divergent Production Regimes: Coordinated and Uncoordinated Market Economies in the 1980s and 1990s'. In Kitschelt, H., Lange, P., Marks, G. and Stephens, J. D. (eds) Continuity and Change in Contemporary Capitalism, pp. 101-134. Cambridge, Cambridge University Press.

Suddaby, R. and Greenwood, R. (2005) 'Rhetorical Strategies of Legitimacy', Administrative Science Quarterly, 50, 35-67.

Witzel, A. and Reiter, H. (2012) The Problem-Centred Interview. Sage.

Yoshikawa, T., Tsui-Auch, L. S. and McGuire, J. (2007) 'Corporate Governance Reform as Institutional Innovation: The Case of Japan’, Organization Science, 18, 973-988. 


\title{
Promoting social acceptance of energy transition: beyond Western societies
}

\author{
Sijeong Lim $^{1, *}$ and Seiki Tanaka ${ }^{2, * *}$ \\ ${ }^{1}$ Korea University; ${ }^{2}$ University of Leeds \\ ${ }^{*}$ Correspondence: sijeonglim@korea.ac.kr \\ ${ }^{* *}$ Correspondence: s.k.tanaka@leeds.ac.uk
}

\section{Introduction}

When do energy transition policies enjoy broad-based acceptance? Existing scholarly and policy papers suggest that the key is to assure voters of the fairness of the transition and, in particular, the fairness concerning how the transition's short-term costs are shared among different economic classes (Kallbekken et al., 2010; European Commission, 2015). Taxes on fossil-fuel consumption, the most common and fiscally important policy instrument for energy transition, are believed to impose a disproportionate burden on the worst-off members of the society who spend a larger share of income on heating and commuting (Kosonen, 2012; Chiroleu-Assouline and Fodha, 2014). The perceived regressiveness of such taxes has been a 'decisive obstacle to their further consideration in public debates' (Combet et al., 2010). Accordingly, growing attention is paid to countering the regressiveness perception by promoting 'pro-poor' energy transitions. European Environmental Agency (2011, p. 5), for instance, notes that 'the recycling of revenues is especially important for the acceptability and equity of the [environmental] tax reforms'. Some studies indeed find that environmental taxes enjoy greater support when packaged with pro-poor elements (e.g. Kallbekken and Sælen, 2011 in Norway; Dietz and Atkinson, 2010 in the UK).

One caveat, however, is that discussions on socially acceptable energy transition have largely been confined to the West. This exploratory paper seeks to extend the discussion by incorporating broader socio-economic settings. We are especially interested in gauging the effectiveness of pro-poor policy design and framing in promoting public acceptance of energy transition. In this paper, 'pro-poor' energy transitions are broadly defined as those involving various progressive schemes that compensate for or mitigate the distributive losses imposed on the poor. We posit that their effect on the popular acceptance of energy transition varies across countries, and more importantly, there is a divide between Western and non-Western societies. In Section 2, we elaborate our rationale behind this proposition. In Section 3, we provide tentative evidence supportive of our proposition. In Section 4, we discuss the implications of our findings.

\section{Pro-poor policy design and popular acceptance of energy transition}

Pro-poor energy transitions that appeal to the Western public may not resonate well with the public in many, including the most advanced, non-Western countries for two reasons: (a) the lack of an individual-level nexus between environmentalism and economic progressivism; and (b) a weak social norm of redistributive fairness. First, in the West, 
pro-environment citizens who form the core support base for an energy transition tend to be economically progressive. Since as early as the 1970s, successful political mobilization of environmental demands in North America and Europe has been part of a wider left-wing platform (Pepper et al., 1984). Across Western democracies, the self-identified leftists or left party voters tend to be more pro-environment than the self-identified right-wing or conservative party voters (Neumayer, 2004; Nawrotzki, 2012). This positive coupling between environmentalism and economic progressivism is important because more pro-environment citizens have a stronger potential to be 'issue-specific opinion leaders' (Nisbet and Kotcher, 2009) and influence the broader public opinion on energy transition policies. These citizens are likely to rally support for policies that protect the economically vulnerable as well as the environment. While the origin of the nexus would require separate historical analyses, we speculate that market skepticism might serve as their common ideational ground; government social and environmental interventions are both viewed as a remedy against unfettered, market-oriented growth and an effort to re-embed the market relations to social/biospheric relations (Meadowcroft, 2005).

In contrast, in non-Western countries, the common ground between those supporting progressive redistribution and those supporting environmental intervention is weak if not absent. Market skepticism certainly is not their ideational common ground in Asia's (newly) industrialized countries. The dominant discourse for promoting environmental intervention in these countries has been the 'green growth', initially proposed by South Korean conservative politicians (Moon, 2010). Rather than promoting socio-ecological transformation, the discourse focuses narrowly and explicitly on the instrumental use of environmental intervention to develop competitive advantage in the international economy (Jacobs, 2012; Lorek and Spangenberg, 2014). Pro-environment citizens in such societies are thus no natural allies of a pro-poor energy transition.

Second, regardless of individual-level environmental and redistributive preferences, the general public are more likely to accept a pro-poor energy transition in a society with longstanding social protection institutions. This is because the social norms legitimizing government interventions are endogenous to existing institutions (Bowles, 1998). Countries differ in their institutional configurations governing economic activities of production and distribution (Witt et al., 2017). In countries where the state has long been involved in progressive redistribution and social protection, the relevant institutions have interpretive and cognitive effects on citizens (Pierson, 1993) who over time internalize the norm of redistributive fairness. Irrespective of an intervention's first-order objective, an intervention consistent with the norm of redistributive fairness (i.e. providing more benefits to the less advantaged) enjoys public acquiescence, while an intervention that violates this norm (i.e. making the less advantaged worse off) faces public reluctance.

The norm of redistributive fairness is unlikely to prevail where redistribution and social protection have not featured prominently in government policies and institutions. While there might be variation among non-Western countries (as well as Western ones), the case of newly-industrialized Asian countries with minimalist welfare states are particularly worth noting. Existing studies suggest that individuals in these countries have been incorporated into the structure and ethos of the 'developmental state' that promoted high levels of productive investments to upgrade the production structure (Witt and Redding, 2013; Wade, 2018), and developed a 'developmental mindset' (Thurbon, 2016). Citizens with such a socialization experience may grant legitimacy to an intervention that is perceived to promote 
national economic growth. The intervention's distributive effects on different classes might not weigh much with them. For the two reasons outlined in this section, we expect pro-poor energy transition policies to receive less public support in non-Western societies than in the West.

\section{Empirical analysis}

We begin by providing evidence that the individual-level nexus between environmentalism and economic progressivism is unique to the West. We use the 6th wave of the World Value Survey and create a Pro-Environment Index (PEI) and a Pro-Redistribution Index (PRI). See Appendix for the list of sub-components included in each index and summary statistics. We fit a series of linear mixed effect models employing PRI as the dependent variable. We estimate country-specific random slopes for PEI as well as random intercepts. We control for a set of individual-level attributes (age, gender, income, perceived economic insecurity and education) and a country-level attribute (GDP per capita). We are primarily interested in how the coefficient estimates of PEI vary between countries. We visualize our finding in Figure 1. See Appendix for the full results table. For each country, the dot indicates the PEI effect (i.e. random plus fixed slope) and the horizontal line captures $95 \%$ confidence intervals. We observe a positive and significant association between PEI and PRI in only nine out of the 57 countries. The association is positive in all six Western industrialized countries in our sample (i.e. the USA, New Zealand, Australia, Sweden, Netherlands and Spain). The 'Western-ness' of the nexus is clearly illustrated by the fact that the association between the two indices is close to zero in the wealthiest Asian (e.g. Singapore and Japan) and Middle Eastern countries (e.g. Qatar and Kuwait), indicating that the correlation is not an artifact of national wealth.

It is also worth noting that in ten countries (i.e. Egypt, China, Armenia, Tunisia, Pakistan, Slovenia, Ecuador, Kazakhstan, India and South Africa) PEI and PRI have a significant and negative association, suggesting that more pro-environment citizens in these countries are less likely to endorse progressive redistribution. In these countries, adopting propoor framing would not be the best strategy for promoting energy transition. It can even risk undermining the core support base for energy transition by alienating those citizens who would otherwise be most sympathetic to its environmental objectives.

Next, we examine an implication of our second point that societies vary in terms of prevailing standards legitimating government intervention. The public socialized under weak social protection institutions would be insensitive to redistributive fairness. To illustrate our point, we conducted a survey experiment in Taiwan, which is considered an appropriate case for three reasons: (a) it is a high-income democracy, so it allows us to control for income and regime type explanations; (b) the government has ambitious plans for energy transitions including a ban on the sale of all fossil-fuel vehicles by 2040, so our hypothetical scenario is realistic; and (c) we expect the norm of redistributive fairness to be weak in the country, given its minimalist welfare state.

Our 800 respondents were selected from the National Chengchi University Election Study Center's online opt-in panel. Stratified random sampling was used to gain a reasonably good approximation of the general population. The respondents first read a hypothetical government proposal concerning a tax increase on diesel/petrol cars. We primed all respondents with the environmental purpose of the tax by providing information that such cars are major sources of the country's air pollution. Then, they read a proposal to increase 
Effect of Environmentalism on Support for Redistribution

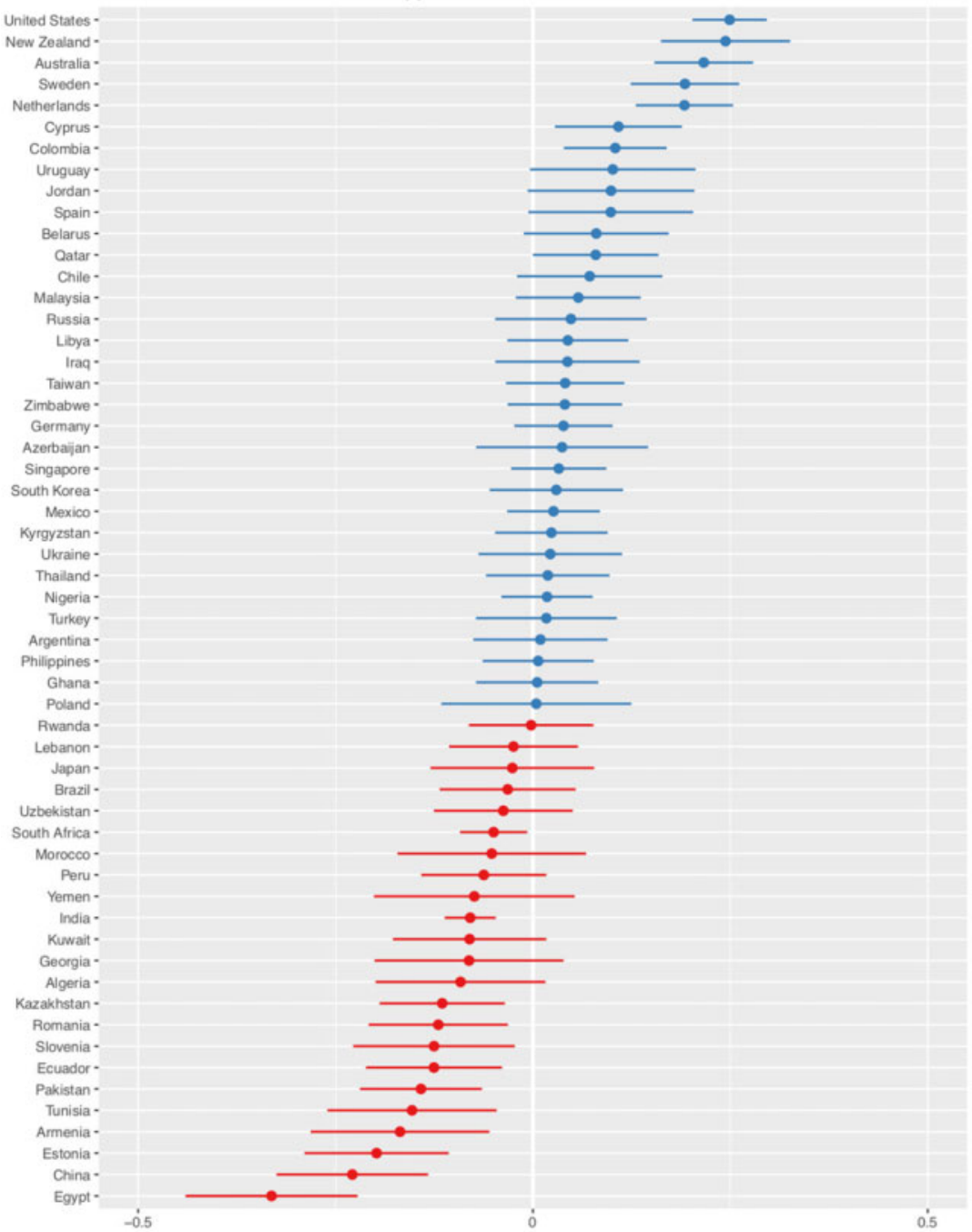

Figure 1 Country-specific association between PEI and PRI.

taxes on the ownership of such cars. Note that Taiwan is a country where car ownership is common across different economic classes. In our survey, over a majority of low-income (first quintile) households own diesel/petrol car and are thus affected by the proposed tax increase. We then randomly assign four pieces of additional information. The control group (C) is just told that the government seeks to discourage the ownership of petrol/diesel cars; they receive no information about the use of the revenue. The three treatment groups receive distinct pieces of information about the use of the revenue. Respondents in T1 are told that the revenue would be used to provide subsidies to low income earners who purchase hybrid/ electronic cars. Those in T2 are told that the government would use the revenue to provide 


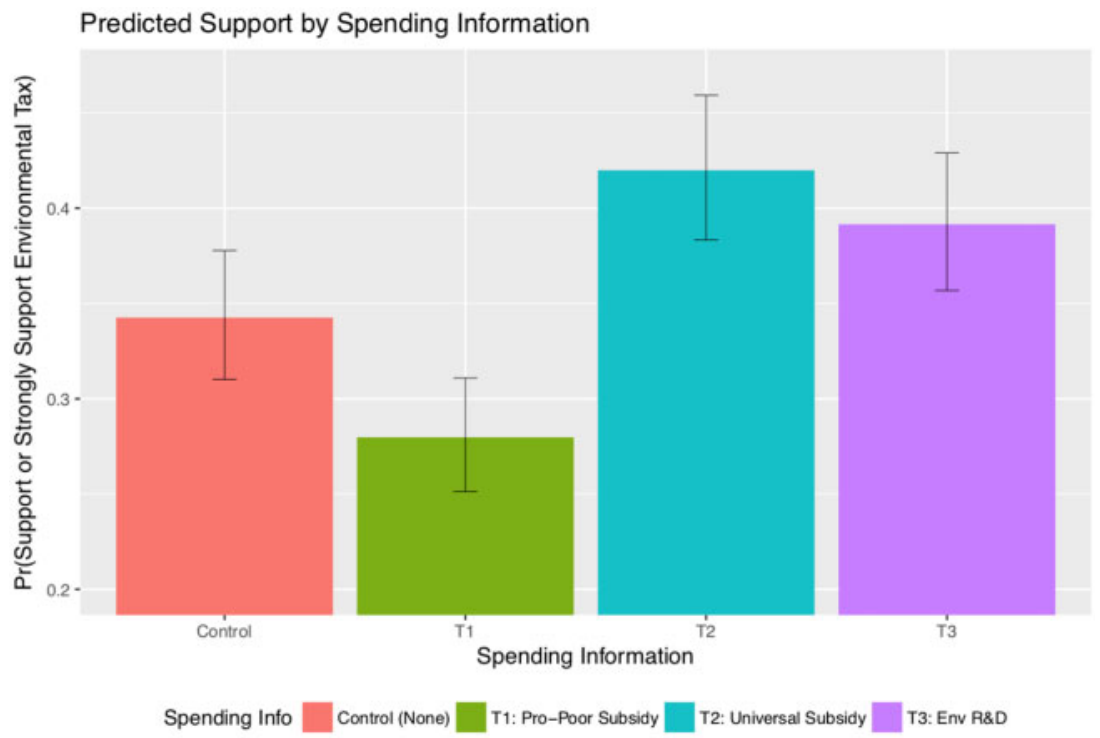

Figure 2 Pro-poor proposal reduces the support for environmental tax.

subsidies to anyone who purchases hybrid/electronic vehicles. Lastly, respondents in T3 read that the revenue would be used for research and development on environmentally friendly vehicles.

The respondents choose their position on the proposal on a 5-point ordinal scale from $1=$ strongly oppose to $5=$ strongly support. By comparing respondent position across the groups, we can examine whether the provision of spending information matters, and if so, which specific information best resonates with the public. To estimate the effect of the different information treatments, we employ an ordered logit model and control for potential confounding factors. Figure 2 reports predicted probabilities that a representative individual in our sample supports environmental tax when provided with four different pieces of information. All control variables are set at the sample mean. Given the modest sample size, we indicate $67 \%$ confidence intervals.

Figure 2 shows that respondents informed about pro-poor subsidy (T1) exhibits a lower level of support than the control group (C). Only $27 \%$ of respondents in this group support (i.e. strongly support or support combined) the proposal, whereas $36 \%$ of the control group respondents do. Further, the universal subsidy treatment group (T2) shows the highest level of support (45\%), followed by the environmental R\&D group (T3, 39\%). See Appendix for the full results table. Our finding might be driven by the self-interest of the respondents; the pro-poor subsidy proposal receives the lowest support because a representative individual in our sample is an average income earner ineligible for such a subsidy.

To further investigate this explanation, Figure 3 reports the predicted probability that low-income and middle-income individuals would support the four proposals respectively. If self-interest drives the finding, low-income individuals should be as favorable to the propoor subsidy proposal as to the universal subsidy proposal. Contrary to this expectation, we find that even among the low-income group (first income quintile), the support level is 


\section{Predicted Support by Spending Information and Income}

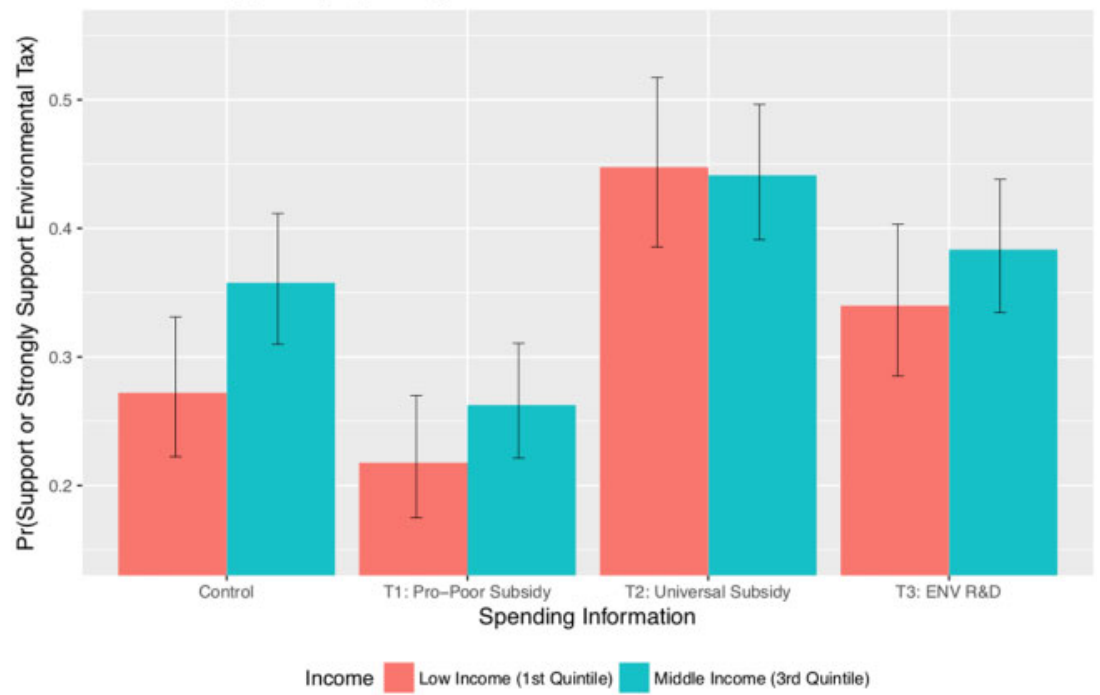

Figure 3 Pro-poor proposal reduces the low-income citizens' support for environmental tax.

markedly lower in T1 $(22 \%)$ than in other groups. The low income's support for the proposal with environmental vehicles R\&D (T3) is 34\%, more than 10 percentage points higher than their support for the proposal with a pro-poor subsidy. The proposal with a universal subsidy (T2) is the most preferred among the low income as well. There is also a possibility that one's perceived economic position is not congruent with an objective measure of economic class such as income. Due to misperception or misinformation, some low-income respondents in T1 might fail to recognize that they are the beneficiaries of the pro-poor subsidy. We thus examined the preferences among those respondents who think they are the bottom $20 \%$. Even among the self-identified poor, the support level is lower in T1 than in other groups. Again, the support level is highest in T2 treated with a universal subsidy plan. The results are available upon request.

What then explains the high popularity of the universal subsidy proposal? Here, we offer a tentative explanation and leave the more rigorous analysis to future research. Citizens in emerging economies including Taiwan are used to low-contribution-low-benefit fiscal structures, and thus lack experience of complying with extensive tax rules and receiving commensurate public goods in return. At the same time, class-based cleavages have never been at the center stage of Taiwanese domestic politics, which has long been dominated by cross-strait relations. In such a socio-economic setting, an increase in tax burden might spur concerns primarily about reciprocity vis-à-vis the government, rather than about between-classes distribution. If so, citizens should foremost be assured that their contribution would be reciprocated by the government. The proposed subsidy to any citizen who is switching to environmentally friendly vehicles offers such an assurance. In contrast, confining the returns to lower-income citizens fails to assure the broad public of reciprocity. As it induces a mismatch between contributors and beneficiaries, the pro-poor subsidy might be seen to be in conflict with the reciprocity standard. As for the environmental $R \& D$, the proposal offers only a weak assurance 
of reciprocity due to the long-term and less tangible nature of R\&D benefits. This somewhat offsets the proposal's potential appeal to Taiwanese with a developmental mindset.

\section{Implications}

The discussion on socially acceptable energy transitions has largely been confined to the context of Western societies. Our exploratory study calls for caution in applying policy recommendations derived from the Western setting to the non-Western context. We find that in most non-Western societies, pro-environment individuals are no more economically progressive than the rest of the population. In such countries where pro-environment citizens tend to be economic conservatives, promoting an explicitly pro-poor policy design risks undermining the much-needed support base for initiating energy-transition programmes. Further, societies vary in terms of the prevailing norms legitimizing government interventions. Our survey experiment in Taiwan-where the norm of redistributive fairness is expected to be weak-finds that a pro-poor revenue recycling scheme undermines public support for an environmental tax proposal. In Taiwan and other emerging economies, emphasizing universalistic and tangible returns and thereby assuring the public of fiscal reciprocity can be an effective way of promoting energy transitions. Future research on socially acceptable energy-transition policies should pay greater attention to the distinct socio-economic contexts of different societies. Particularly useful would be cross-country experimental studies on the relative popularity between universalistic and progressive policy design, as well as between modest tangible returns and large yet less tangible returns.

\section{Funding}

Sijeong Lim was supported by Korea University Research Seed Grants (K1826471, K1824211).

\section{References}

Bowles, S. (1998) 'Endogenous Preferences: The Cultural Consequences of Markets and Other Economic Institutions', Journal of Economic Literature, 36, 75-111.

Chiroleu-Assouline, M. and Fodha, M. (2014) 'From Regressive Pollution Taxes to Progressive Environmental Tax Reforms', European Economic Review, 69, 126-142.

Combet, E., Ghersi, F., Hourcade, J. C. and Thery, D. (2010) 'Carbon Tax and Equity: The Importance of Policy Design'. In Dias Soares, C. (eds) Critical Issues in Environmental Taxation, pp. 277-295. Oxford, Oxford University Press.

Dietz, S. and Atkinson, G. (2010) 'The Equity-Efficiency Trade-off in Environmental Policy: Evidence from Stated Preferences', Land Economics, 86, 423-443.

European Environmental Agency. (2011) Environmental Tax Reform in Europe: Implications for Income Distribution, Technical report No 16/2011.

European Commission. (2015) 'Tax Reforms in eu Member States 2015-Tax Policy Challenges for Economic Growth and Fiscal Sustainability'. European Commission Institutional Papers 8.

Jacobs, M. (2012) 'Green Growth: Economic Theory and Political Discourse', Centre for Climate Change Economics and Policy Working Paper 108.

Kallbekken, S., Kroll, S., Cherry, T. L. (2010) 'Pigouvian Tax Aversion and Inequity Aversion in the Lab', Economics Bulletin, 30, 1914-1921.

Kallbekken, S. and Sælen, H. (2011) 'Public Acceptance for Environmental Taxes: Self-Interest, Environmental and Distributional Concerns', Energy Policy, 39, 2966-2973. 
Kosonen, K. (2012) Regressivity of Environmental Taxation: Myth or Reality? Handbook of Research on Environmental Taxation, pp. 161-174. Cheltenham, Edward Elgar Publishing.

Lorek, S. and Spangenberg, J. H. (2014) 'Sustainable Consumption within a Sustainable Economy-Beyond Green Growth and Green Economies', Journal of Cleaner Production, 63, 33-44.

Meadowcroft, J. (2005) 'From Welfare State to Ecostate', In Barry, J. and Eckersley, R. (eds) The State and the Global Ecological Crisis, Cambridge, MA, MIT Press, pp. 3-23.

Moon, T. H. (2010) 'Green Growth Policy in the Republic of Korea: Its Promise and Pitfalls', Korea Observer, 41, 379.

Nawrotzki, R. J. (2012) 'The Politics of Environmental Concern: A Cross-National Analysis', Organization \& Environment, 25, 286-307.

Neumayer, E. (2004) 'The Environment, Left-Wing Political Orientation and Ecological Economics', Ecological Economics, 51, 167-175.

Nisbet, M. C. and Kotcher, J. E. (2009) 'A Two-Step Flow of Influence? Opinion-Leader Campaigns', On Climate Change. Science Communication, 30, 328-354.

Pepper, D., Perkins, J. W. and Youngs, M. J. (1984) The Roots of Modern Environmentalism. London, Croom Helm.

Pierson, P. (1993) 'When Effect Becomes Cause: Policy Feedback and Political Change', World Politics, 45, 595-628.

Thurbon, E. (2016) Developmental Mindset: The Revival of Financial Activism in South Korea. Ithaca, NY, Cornell University Press.

Wade, R. H. (2018) 'The Developmental State: Dead or Alive?', Development and Change, 49, 518-546.

Witt, M. A., Kabbach de Castro, L. R., Amaeshi, K., Mahroum, S., Bohle, D., and Saez, L. (2017) 'Mapping the Business Systems of 61 Major Economies: A Taxonomy and Implications for Varieties of Capitalism and Business Systems Research', Socio-Economic Review, 16, 5-38.

Witt, M. A. and Redding, G. (2013) 'Asian Business Systems: Institutional Comparison, Clusters and Implications for Varieties of Capitalism and Business Systems Theory', Socio-Economic Review, 11, 265-300.

Table A1 Pro environment and pro redistribution indexes

\begin{tabular}{ll}
\hline & Pro Environment Index Components \\
V30 & Active/Inactive Environmental Organization Membership \\
V78 & Looking After the Environment is Important \\
V81 & Protecting Environment vs. Economic Growth \\
V82 & Given Money to Ecological Organization \\
V83 & Participated in Environmental Demonstration \\
& Pro Redistribution Index Components \\
V96 & Income Should be Made More Equal \\
V98 & Government Should Ensure that Everyone is Provided for \\
V131 & (Essentials of Democracy) Government Tax the Rich and Subsidize the Poor \\
V134 & (Essentials of Democracy) People Receive State Aid for Unemployment \\
V137 & (Essentials of Democracy) The State Makes Peoples' Incomes Equal \\
\hline
\end{tabular}

Note: We employ Principal Component Analysis-based aggregation method. For robustness check, we also tried an alternative method of aggregation (geometric average), and our findings hold. 